\title{
Basic Studies of UII-V High Efficiency Cell Components
}

NREJ/TP-451-4850

DE92 010563

\section{Annual Subcontract Report 15 August 1989 - 14 August 1990}

M. S. Lundstrom, M. R. Melloch, R. F. Pierret, M. S. Carpenter, H. L. Chuang, P. E. Dodd, A. Keshavarzi, M. E. Klausmeier-Brown, G. B. Lush, T. B. Stellwag

Purdue University

West Lafayette, Indiana

NREL technical monitor: J. Benner

\section{NPE}

National Renewable Energy Laboratory (formerly the Solar Energy Research Institute) 1617 Cole Boulevard

Golden, Colorado 80401-3393

A Division of Midwest Research Institute Operated for the U.S. Department of Energy under Contract No. DE-AC02-83CH10093

Prepared under Subcontract No. XL-5-0518-1 January 1993 
This publication was reproduced from the best available camera-ready copy submitted by the subcontractor and received no editorial review at NREL.

\title{
NOTICE
}

This.report was prepared as an account of work sponsored by an agency of the United States government. Neither the United States government nor any agency thereof, nor any of their employees, makes any warranty, express or implied, or assumes any legal liability or responsibility for the accuracy, completeness, or usefuiness of any information, apparatus, product, or process disclosed, or represents that its use would not intringe privately owned rights. Reference herein to any specific commercial product, process, or service by trade name, trademark, manufacturer, or otherwise does not necessarily constitute or imply its endorsement, recommendation, or favoring by the United States government or any agency thereof. The views and opinions of authors expressed herein do not necessarily state or reflect those of the United States government or any agency thereof.

\author{
Printed in the United States of America \\ Available from: \\ National Technical Information Service \\ U.S. Department of Commerce \\ 5285 Port Royal Road \\ Springfield, VA 22161
}

Price: Microfiche A01

Printed Copy A04

Codes are used for pricing all publications. The code is determined by the number of pages in the publication. Information pertaining to the pricing codes can be found in the current issue of the following publications which are generally available in most libraries: Energy Research Abstracts (ERA); Government Reports Announcements and Index (GRA and I); Scientific and Technical Abstract Reports (STAR); and publication NTIS-PR-360 available from NTIS at the above address. 


\section{DISCLAIMER}

Portions of this document may be illegible electronic image products. Images are produced from the best available original document. 


\section{PREFACE}

This project's objective is to improve our understanding of the generation; recombination, and transport of carriers within III-V homo- and heterostructures. The research itself consists of fabricating and characterizing solar cell "building blocks" such as junctions and heterojunctions as well as basic measurements of material parameters. A significant effort is also being directed at characterizing loss mechanisms in high-quality, III-V solar cells fabricated in industrial research laboratories throughout the United States. The project's goal is to use our understanding of the device physics of high-efficiency cell components to maximize cell efficiency. A related goal is the demonstration of new cell structures fabricated by molecular beam epitaxy (MBE). The development of measurement techniques and characterization methodologies is also a project objective.

This report describes our progress during the fifth and final year of the project. During the past five years, we've learned a great deal about heavy doping effects in $\mathrm{p}^{+}$and $\mathrm{n}^{+} \mathrm{GaAs}$ and have explored their implications for solar cells. We have developed an understanding of the dominant recombination losses in present-day, high-efficiency cells. We've learned to appreciated the importance of recombination at the perimeter of the cell and have developed techniques for chemically passivating such edges. Finally, we've demonstrated that films grown by molecular beam epitaxy are suitable for high-efficiency cell research.

For the past year, our efforts have been directed at finishing up several of our on-going studies. Effects of heavy doping on GaAs solar cells were addressed in a paper presented at the 21st Photovoltaic Specialists Conference. We completed studies of perimeter recombination and developed a computer model to simulate such effects. The importance of perimeter recombination for GaAs solar cells and for diagnostic measurements was addressed in another PVSC paper. A new chemical treatment capable of permanently passivating GaAs surfaces was demonstrated. In collaboration with Professor R.L. Gunshor of Purdue, we also passivated an MBE-grown, $\mathrm{n}$ on $\mathrm{p}, \mathrm{GaAs}$ solar cell with an MBE-grown, pseudomorphic ZnSe layer. (Cell fabrication and electrical characterization is now underway.) Finally, solar cell applications of MBE-grown cells were demonstrated. High-efficiency $\mathrm{GaAs}$ cells as large as $2 \mathrm{~cm}$ by $4 \mathrm{~cm}$ were demonstrated, and an $\mathrm{Al}_{0.2} \mathrm{Ga}_{0.8}$ As with record efficiency was demonstrated.

Success in this work would not have been possible without the generous cooperation of colleagues in industry. We owe special thanks to Steve Tobin, Stan Vernon, and their colleagues at Spire Corporation for sharing their knowledge of high-efficiency cells and for fabricating GaAs and AlGaAs cells using our MBE-grown films. We also thank Peter Iles, Frank Ho, and Charles Chu from Applied Solar Energy Corporation for working with us to fabricate $2 \mathrm{~cm}$ by $4 \mathrm{~cm}$ GaAs solar cells with MBE-grown films. The work described in this report was supported by the Solar Energy Research Institute. We owe a special debt to Cecile Leboeuf and John Benner for their sustained support during the course of this work. Our research also benefited by collaborations with three graduate student researchers not supported by SERI. Harry Chuang was supported by the Indiana Corporation for Science and and Technology, Martin Klausmeier-Brown by a fellowship from the Eastman Kodak Company, and Paul Dodd by a President's Fellowship from Purdue University. 


\section{SUMMARY}

\section{Project Overview}

Solar cell efficiency is determined both by material quality and by device design. As the efficiencies of both single and multiple junction III-V solar cells continue to rise, it is becoming increasingly important to carefully examine the internal device physics of solar cells so that cell designs can be tailored to the material constraints. The need for a sound understanding of internal device physics is clearly illustrated by the more mature crystalline silicon cell technology. After a broad program of basic studies in the late 1970's, silicon solar cell designers now understand the internal distribution of photocurrent and dark current losses with a high degree of confidence. Silicon cell efficiencies continue to advance, but progress now is largely due to innovative cell designs rather than to improving material quality. The continuing progress in silicon cell efficiencies illustrates the benefits of careful cell design guided by detailed knowledge of device physics.

In comparison to silicon, there has been relatively little work on basic studies of compound semiconductor solar cells. Our work is directed at meeting this need for an improved understanding of the internal device physics and material parameters of compound semiconductor solar cells. The goal is to identify the internal recombination losses that control the performance of stateof-the-art, high-efficiency GaAs-based solar cells and to develop characterization methodologies and approaches that are broadly applicable to compound semiconductor cells. Another aim is to measure for the first time some of the fundamental parameters (such as the effective intrinsic carrier concentration and minority carrier mobility) which control the performance of solar cells. Finally, we aim to apply this evolving device physics knowledge in order to explore new approaches for enhancing solar cell efficiency. While these basic studies are contributing to the steady progress of III-V cell efficiencies, they may at the same time lead to innovative new approaches for achieving substantial efficiency gains.

\section{Scientific and Technical Activities: 1989 - 1990}

During the past year, the specific project objectives were to:

- develop a quantitative understanding of perimeter and surface recombination along with a predictive numerical model to simulate such effects

- explore chemical techniques to permanently passivate GaAs surfaces

- $\quad$ assess the photovoltaic potential of pseudomorphic, $\mathrm{ZnSe} / \mathrm{GaAs}$ heterostructures

- demonstrate high efficiency GaAs and AlGaAs cells using films grown in our MBE facility.

The perimeter and surface recombination studies concluded a long-term effort to understand such effects as well as their implications for III-V solar cells. As a result of this work, we now have a detailed, numerical model which has been verified experimentally.

Earlier work by our group demonstrated that ammonium sulfide treatments suppress perimeter recombination - but only temporarily. During the past year, we have demonstrated that a new arsenic glass treatment, developed by E. Yablonovitch at Bellcore, results in a permanent reduction of perimeter recombination. 
In collaboration with R.L. Gunshor at Purdue, we have successfully grown pseudomorphic ZnSe on a GaAs solar cell film. Measurements to assess the photovoltaic quality of the $\mathrm{ZnSe} / \mathrm{GaAs}$ interface are underway.

Finally, work to assess the photovoltaic quality of GaAs films grown in our MBE facility continued. In last year's report, we described a $23.8 \% 0.5 \mathrm{~cm}$ by $0.5 \mathrm{~cm}$ heteroface cell fabricated at Spire Corporation using a Purdue-grown MBE film. This year Spire also fabricated a $16.1 \%$ $\mathrm{Al}_{0.2} \mathrm{Ga}_{0.8} \mathrm{As}$ solar cell using Purdue-grown material. This result is a record for MBE-grown AlGaAs. Because it was grown at a temperature lower than optimum, however, we expect that much higher efficiencies will be achieved. Finally, we collaborated with Applied Solar Energy Corporation to fabricate large area $(2 \mathrm{~cm}$ by $4 \mathrm{~cm}$ ) GaAs solar cells. The MBE-grown film had an average cell efficiency of $18.8 \%$ (AM0) which is comparable to results obtained for similar size cells fabricated from MOCVD material. These results are important because they demonstrate that MBE-grown films are suitable for high-efficiency cell research.

\section{Major Project Accomplishments}

Since this is the final project report describing this five-year effort, it seems appropriate to review the major project accomplishments. The references listed below refer to those listed in Appendix 1.

1) Identification of heteroface and perimeter recombination as significant loss factors in high-efficiency GaAs cells [2,37]. (By focusing on these losses, researchers at Spire Corporation later achieved 1-sun record efficiency GaAs cells.)

2) First measurement of barrier recombination velocity of $p^{+}-p$ back-surface-fields and demonstration that this conventional feature of cell design was ineffective [15,18].

3) Demonstration that AlGaAs buffer layers provide a useful gettering benefit in solar cell applications [31]. (This design feature is now a part of Spire's record efficiency GaAs cell.)

4) First measurements of effective bandgap shrinkage in $\mathbf{p}^{+}-\mathrm{GaAs}$ [34]. (This work stimulated similar experiments elsewhere and has now been verified by three different laboratories, at Duke University, at IMEC in Belgium, and at IBM's T. J. Watson Lab. The results explain why $\mathrm{p}^{+}-\mathrm{p}$ homojunctions are ineffective minority carrier mirrors and have generated interested within the GaAs bipolar community as well. The work has resulted in two invited talks.)

5) Development and first demonstration of passivation of GaAs surfaces by ammonium sulfide [32]. (A previously reported treatment, sodium sulfide displayed an undersirable shunt leakage. The effectiveness of this treatment has now been verified by a number of laboratories. Researchers at Bellcore find that the ammonium sulfide treatment produces the lowest surface recombination velocity of any of the recently-reported chemical treatments.)

6) Development of isothermal current DLTS for solar cell diagnostics [40]. (Conventional capacitance DLTS is difficult to apply to large area solar cells, but one can readily use current transients. The isothermal technique makes it possible to determine a trap's energy level from a single temperature measurement, which makes the technique useful to routine diagnostic applications.)

7) Characterization of $n^{+} n$ back-surface fields [41]. (This work demonstrated that, in contrast to $\mathrm{p}^{+}-\mathrm{p}$ barriers, these barriers were effective in minority carrier confinement. The results suggests that the effective gap shrinkage that occurs in $\mathrm{p}^{+}-\mathrm{GaAs}$ is relatively minor in $\mathrm{n}^{+}$-GaAs. It confirmed recent work by researchers at RPI and provided additional information on the minority hole diffusion coefficient.) 
8) First chemical analysis of chemically passivated GaAs surfaces [39,42]. (This work, published simultaneously with independent work by Bellcore researchers, used XPS analysis to show that the treated surface was free of oxygen and contained less than one monolayer of sulfur.)

9) Achievement of record efficiency MBE-grown GaAs p/n heteroface cell [23,44]. (The efficiency of this cell was only one percentage point below the best reported efficiency for MOCVD-grown GaAs and demonstrates the high quality of the material now being produced in our MBE facility. The film was the first solar cell film grown in the system and had obvious problems that we expect to correct.)

10) Extension of effective bandgap shrinkage measurements to $N_{A}=10^{20} \mathrm{~cm}^{-3}[4,46,47]$. (This work used a new technique which verified the originally reported results and extended them by one order of magnitude. The work provides data in a doping range commonly encountered for GaAs solar cells and bipolar transistors and displayed some interesting differences with theoretical predictions and with the corresponding result for $\mathrm{p}^{+}-\mathrm{Si}$.)

11) Observation of a strong orientation dependence for perimeter recombination $[4,10,48]$. (This work showed that perimeter recombination currents can vary by a factor of five depending on the crystallographic orientation of the diode. The results may explain some of the variability observed in dark current measurements and may offer a means to minimize this recombination loss.)

12) Demonstration of large-area, high-efficiency MBE-grown GaAs solar cells [53]. (This work demonstrates that the defect densities of MBE-grown films are low enough for highefficiency cell research.)

\section{Overview of the Report}

This report consists of several chapters which describe some of last year's research activities. Other research is described in the reprints contained in Appendix 1. Chapter 1 describes experimental and theoretical work on perimeter and surface recombination. It describes measurements to characterize such recombination as well as the extension of the PUPHS2D model to treat these effects. A new surface passivation treatment, $\mathrm{As}_{2} \mathrm{~S}_{3}$, which appears to produce a permanent reduction of surface recombination is described in Chapter 2. As discussed in Chapter 3 , we have collaborated with outside laboratories to fabricate and characterize a variety of highefficiency cells using MBE-grown films. Finally, in Chapter 4, we present some thoughts on how innovative designs might be used to advantage for III-V cells. The report also contains one appendix. Appendix 1 is a complete list of the publications that have resulted during the course of the project.

\section{Conclusions}

During the past five years, we've learned a great deal about GaAs material properties and solar cell device physics. We now understand much more about the fundamental device physics of GaAs and the importance of various loss mechanisms in state-of-the-art cells. GaAs cell efficiencies continue to rise, but as the material quality improves, the role of cell design becomes increasingly important. With the knowledge gained by these basic studies, it should now be possible to critically assess, with a high degree of confidence, the potential for innovative GaAsbased solar cell designs. 


\section{TABLE OF CONTENTS}

CHAPTER 1: SURFACE and PERIMETER RECOMBINATION in GaAs DIODES .1

CHAPTER 2: $\mathrm{As}_{2} \mathrm{~S}_{3}$ PASSIVATION of GaAs SURFACES .24

CHAPTER 3: LARGE AREA GaAs SOLAR CELLS FABRICATED FROM MBE MATERIAL 34

CHAPTER 4: THE THIN-FILM APPROACH to HIGH EFFICIENCY .44

APPENDIX 1: BIBLIOGRAPHY OF SERI-SUPPORTED PUBLICATIONS .55 


\section{CHAPTER 1}

\section{Surface and Perimeter Recombination in GaAs Diodes: An Experimental and Theoretical Investigation}

\section{Introduction}

Gallium arsenide surfaces contain high densities of charged states and recombination centers which degrade the performance of electronic devices [1]. Recombination at the illuminated surface reduces a solar cell's photocurrent, and recombination along the cell's perimeter increases its dark current [2]. Perimeter recombination similarly degrades the performance of heterojunction bipolar transistors by producing a size effect which reduces the gain of small devices $[3,4]$. To suppress surface and perimeter recombination, a variety of novel device designs and surface treatments are being explored $[5,6]$. A quantitative understanding of surface recombination must be developed in order to analyze and design GaAs bipolar devices. In this chapter, we present a detailed experimental characterization of surface and perimeter recombination in $\mathrm{GaAs} p / \mathrm{n}$ diodes and analyze the experiments using a comprehensive numerical model. The objectives are to gain insight into the nature of surface and perimeter recombination in GaAs devices as well as to develop a quantitative model for device applications.

For the $\dot{p} / n$ heteroface diode illustrated in Fig. 1, recombination along the surface of the $\mathrm{p}^{+}$layer is usually characterized by a minority carrier surface recombination velocity of $S_{F} \approx 10^{7} \mathrm{~cm} / \mathrm{sec}$ [7]. Recombination along the perimeter influences the diode's dark current, which is determined by the integrated recombination rate. By integrating across the junction space-charge region alone, we find the bulk current to be

$$
I_{b}=q A \int_{-X_{P}}^{X_{n}} R(y) d y=\frac{q n_{i e} A}{\tau_{0}} W_{e f f}\left(e^{q V / n_{b} k T}-1\right)
$$




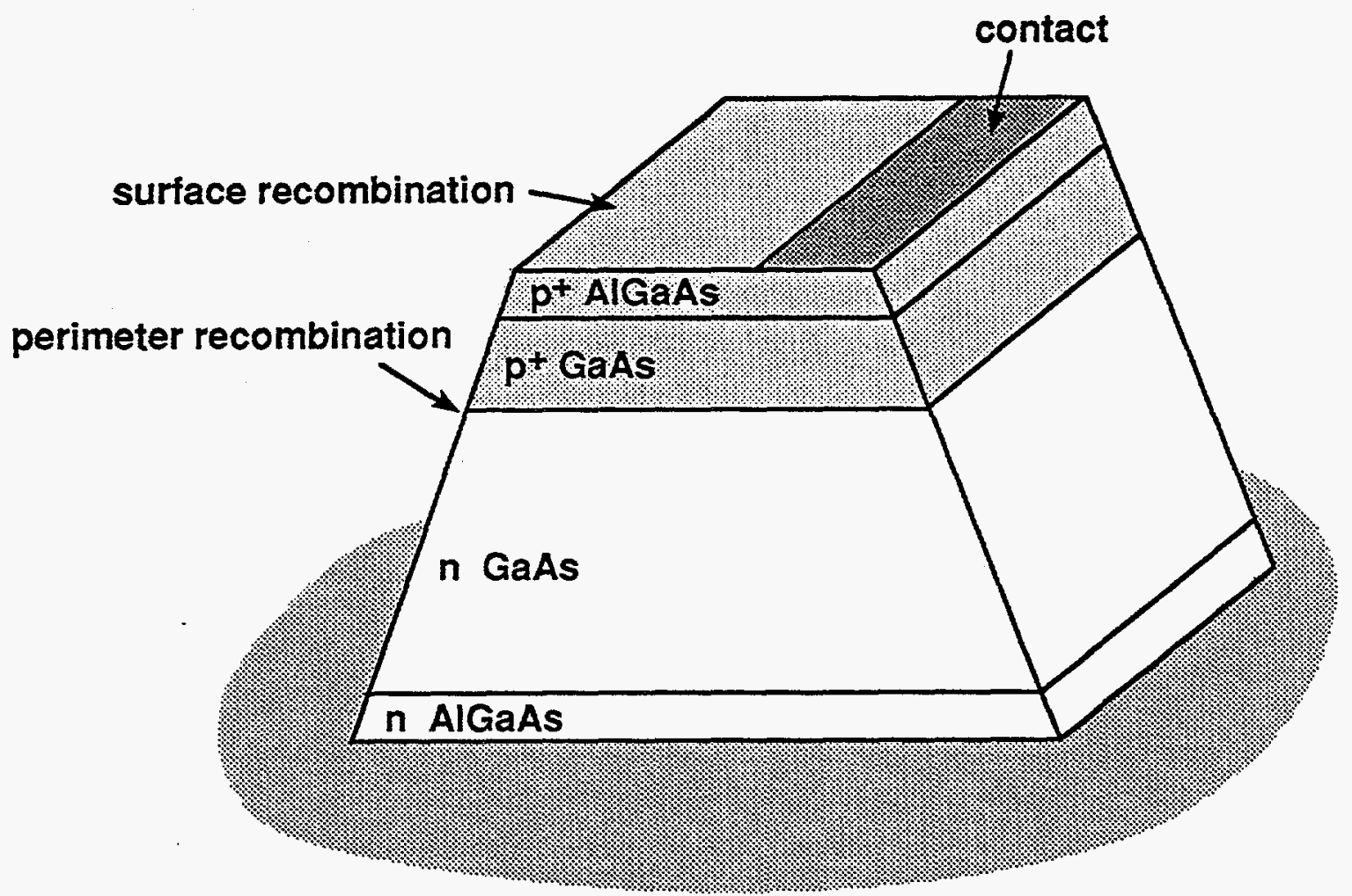

Fig. 1. Typical heteroface diode structure.

where $A$ is the junction area and $\tau_{0}=\sqrt{\tau_{\text {no }} \tau_{\text {po }}}$. The Shockley-Read-Hall (SRH) recombination rate, $R(y)$, peaks where $\tau_{\mathrm{po}} n(y)=\tau_{\mathrm{nop}}(y)$, and the effective width over which recombination occurs is [8]

$$
W_{\text {eff }}=\frac{\pi}{2} \frac{k T / q}{\varepsilon_{y}},
$$

where $\varepsilon_{\mathrm{y}}$ is the electric field normal to the junction where the recombination rate is at its maximum. Recombination in the junction space-charge region typically results in a current with an ideality factor of $\mathrm{n}_{\mathrm{b}} \approx 2$ with $\mathrm{W}_{\text {eff }}$ being a very small fraction of the junction's space-charge region width. 
The perimeter current is obtained by integrating the surface recombination rate along the diode's perimeter,

$$
I_{p}=q P \int R_{S}(y) d y \approx q n_{i e} s_{0} L_{s} P\left(e^{q V / n_{s} k T}-1\right),
$$

where $P$ is the diode's perimeter, $n_{s}$ is the ideality factor associated with the perimeter current, $L_{s}$ is the effective width for surface recombination, and $s_{o}=\sqrt{S_{\text {no }} S_{p o}}$. When there are no charged states at the exposed perimeter, the perimeter current can be decomposed into two components. Where the junction space-charge region intersects the perimeter, we find $n_{s} \approx 2$ and $L_{s} \approx W_{\text {eff }}$ as given in (1b), so this current component produces an $\mathrm{n} \approx 2$ current much like recombination in the bulk space-charge region. Carriers injected into the quasi-neutral regions can also diffuse to the perimeter and recombine which leads to an $n \approx 1$ component of the perimeter current. For the total perimeter recombination current, the ideality factor varies with bias from $\mathrm{n} \approx 2$ at low biases to $\mathrm{n} \approx 1$ at high biases.

In $\mathrm{GaAs}$, surface states tend to deplete the semiconductor near exposed surfaces. Figure 2 shows the equilibrium electrostatic potential versus position for a $\mathrm{p} / \mathrm{n}$ heteroface diode similar to that sketched in Fig. 1. (The electrostatic potential was computed numerically as described in Sec. III.) The band bending produces a surface channel, and the built-in potential of the surface diode is considerably smaller than that of the bulk junction. For this reason, theoretical analyses of perimeter currents have focused on carrier injection and recombination in the surface channel [9,10]. Henry et al. [9] developed an analytical expression for the perimeter current based on a number of assumptions including constant quasi-Fermi levels in the surface space-charge region. Their result is much like (2) with an ideality factor of about 2 , but $L_{s}$ is termed a surface diffusion length and characterizes carrier injection and recombination in the surface channel. In this view, the perimeter current is controlled by recombination in the surface channels outside of the region where the junction space-charge layer intersects the perimeter.

To treat perimeter recombination accurately, detailed numerical solutions are required. Figure 3 shows the forward-biased internal recombination rate within the diode sketched in Fig. 1. Both bulk and perimeter recombination are observed, but perimeter recombination dominates. (The numerical model and the input parameters for this simulation are discussed later. ) The simulation shows recombination where the junction space-charge layer intersects the perimeter as well as within the surface channels. Similar numerical simulations have been employed to examine perimeter recombination in 


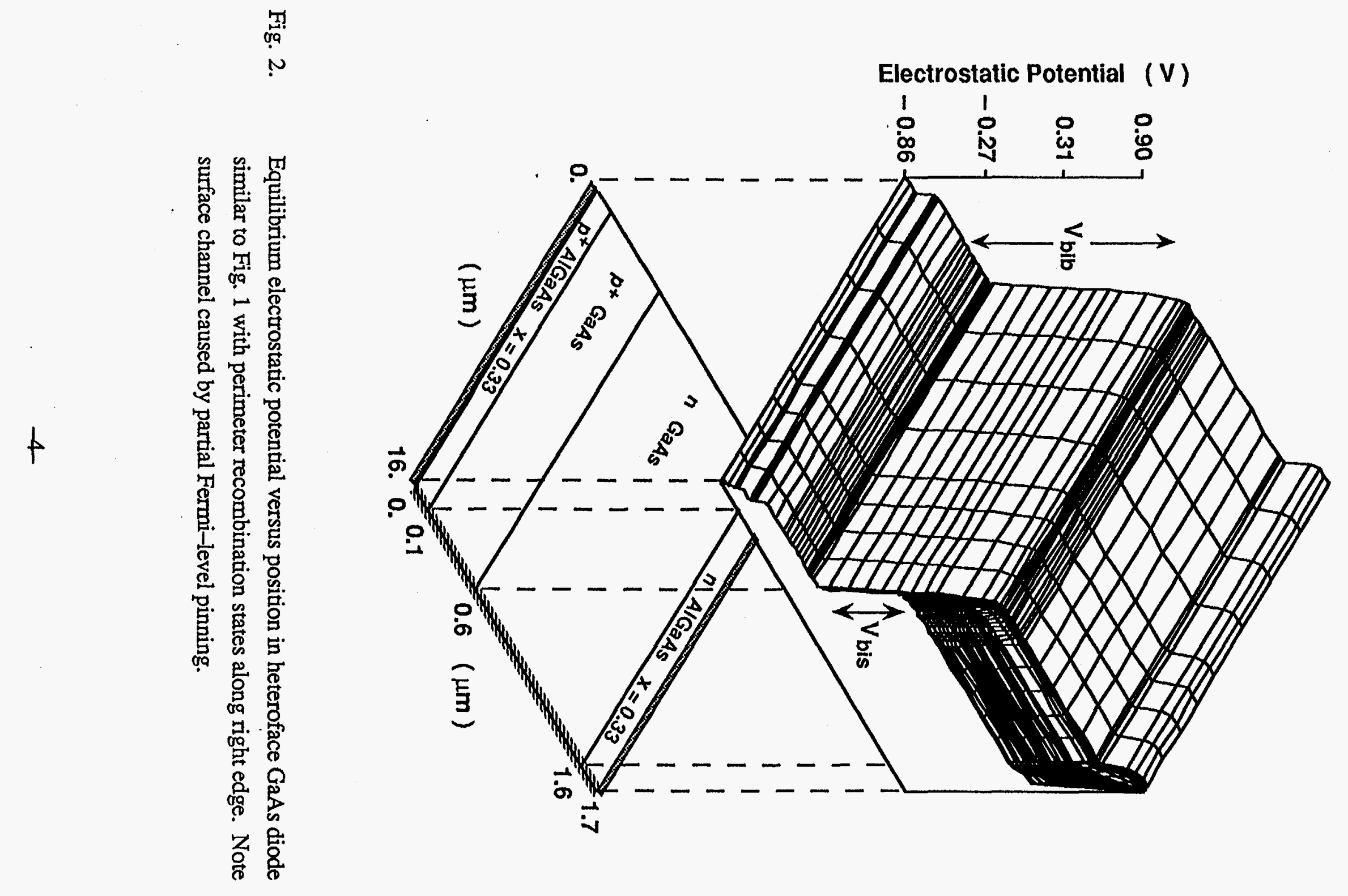




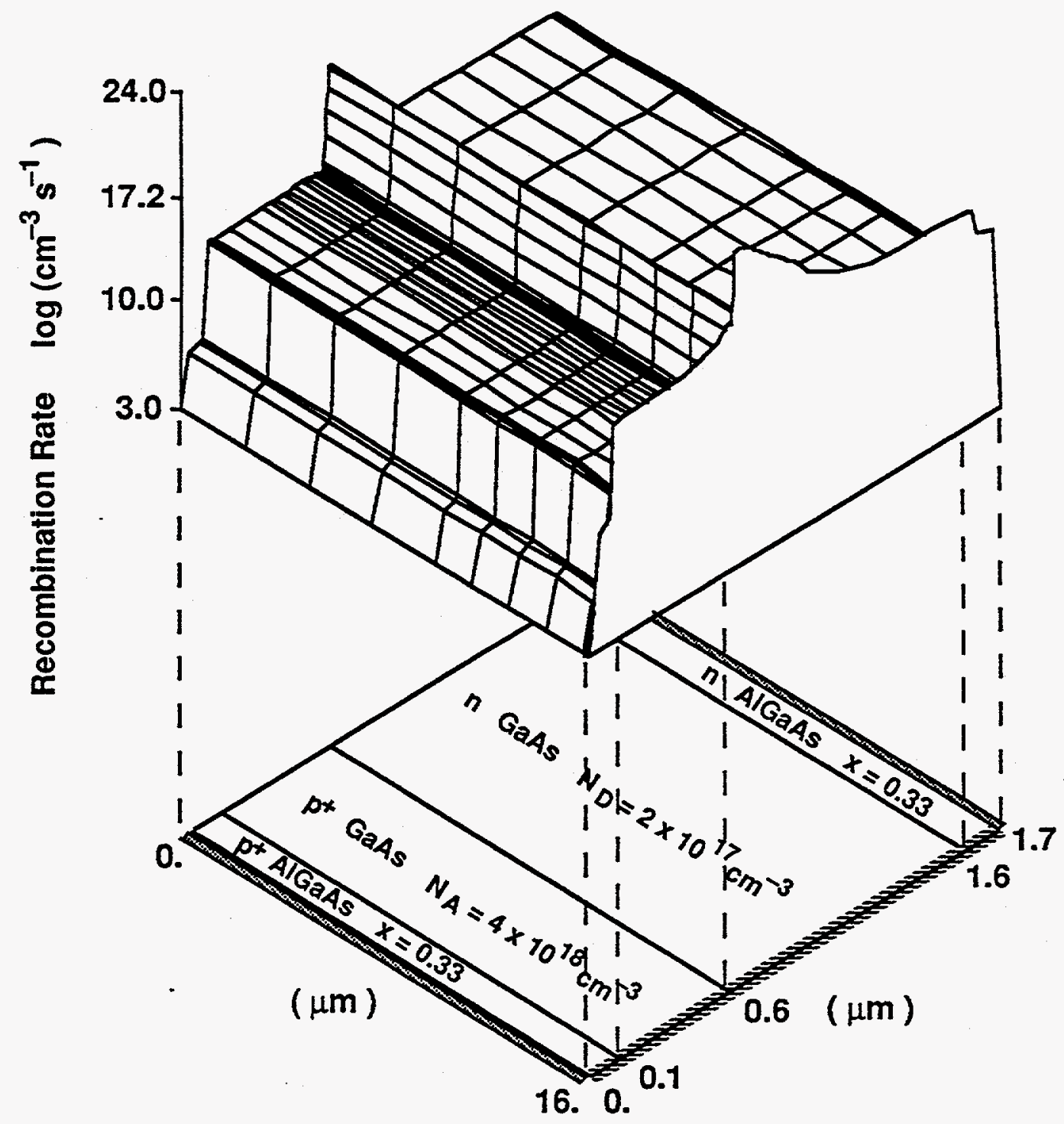

Fig. 3a. Internal volume recombination rate in a GaAs heteroface diode with surface states under $0.6 \mathrm{~V}$ of forward bias. Plotted on logarithmic scale. 


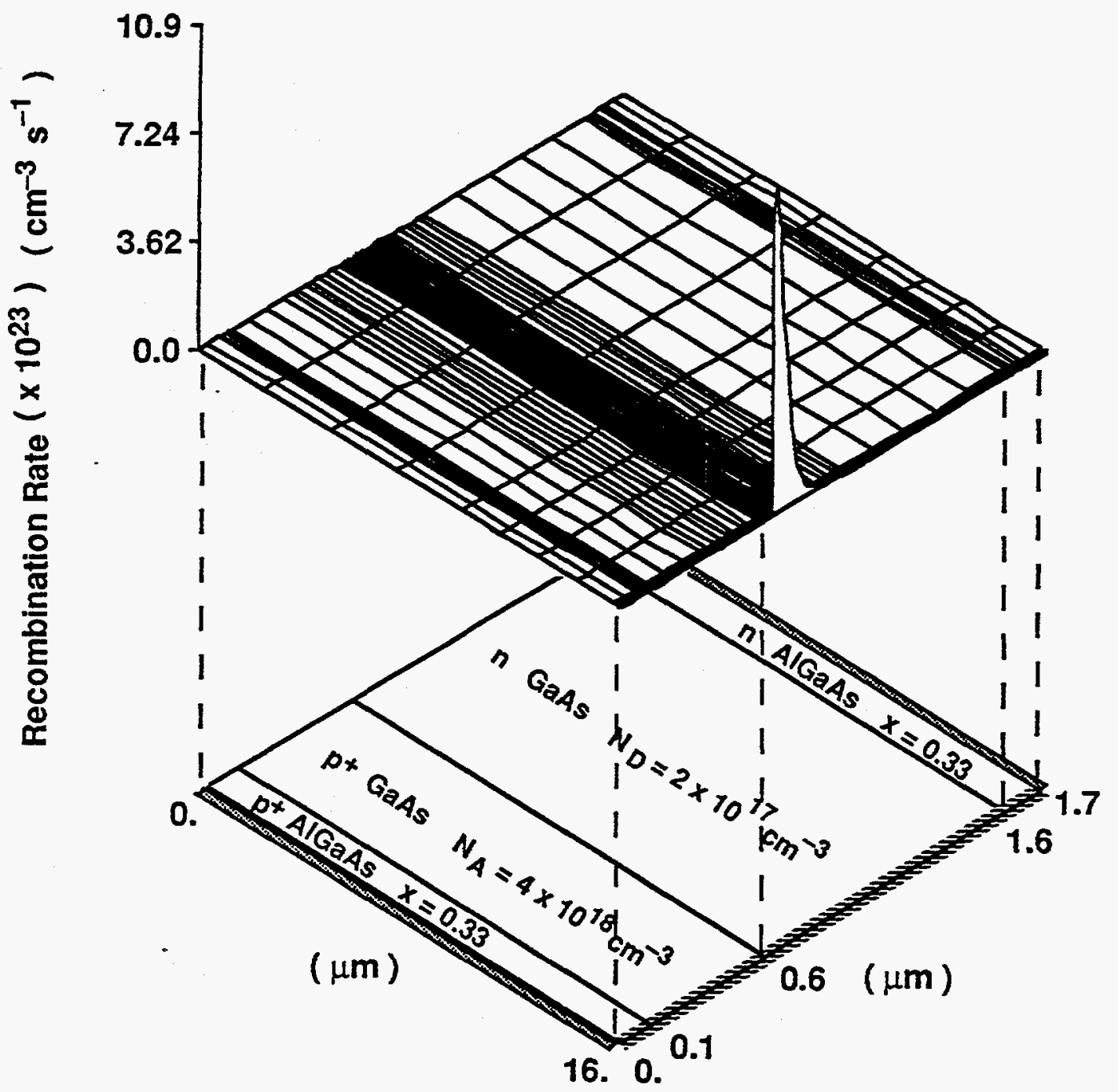

Fig. 3b. Internal volume recombination rate in a GaAs heteroface diode with surface states under $0.6 \mathrm{~V}$ of forward bias. Plotted on linear scale. 
heterojunction bipolar transistors [10,11]. The simulations of Tiwari et al. [10] demonstrate that the constant quasi-Fermi level approximation doesn't apply and that the perimeter recombination current ideality factor has a strong bias dependence. To establish the validity of such models and the values of input parameters such as the surface recombination velocity, detailed comparisons with experiment need to be undertaken.

Our purpose in this chapter is to describe experiments to isolate perimeter and bulk recombination currents in $\mathrm{GaAs} p / \mathrm{n}$ diodes and to compare measured results with numerical simulations. We choose to work with $\mathrm{p} / \mathrm{n}$ homojunction diodes in order to avoid the additional complications introduced by two-dimensional geometries and heterojunctions in devices such as HBT's. Numerical analysis will also be employed to describe the important features of perimeter recombination in GaAs diodes. The results demonstrate that surface and perimeter recombination can be accurately simulated using a simple model for the GaAs surface. Simulation results also demonstrate that carrier injection in the surface channels is not the controlling factor in these devices. These results clarify the important features of perimeter and surface recombination in $\mathrm{GaAs}$ diodes and should serve as a useful guide for what to expect in more complex, heterojunction devices.

This chapter is organized as follows. In Sec. II, we describe the experimental work to characterize surface and bulk recombination currents in $\mathrm{GaAs} p / n$ junction diodes. The numerical model used to simulate the experiment is described in Sec. III, and in Sec. IV we compare simulated and measured results. We discuss the results in Sec. V and summarize the main conclusions in Sec. VI.

\section{Experimental Results}

\section{Film Growth.and Device Processing}

The structure of Fig. 1 was designed to suppress the bulk diffusion current so that perimeter recombination could be explored. The device uses heteroface barriers to reduce this surface recombination by surrounding the $\mathrm{GaAs} \mathrm{p}^{+} / \mathrm{n}$ junction with the wider-bandgap material $\mathrm{Al}_{\mathrm{x}} \mathrm{Ga}_{1-\mathrm{x}} \mathrm{As}$. Since this technique greatly suppresses the $\mathrm{n}=1$ current component, the $n \approx 2$ perimeter recombination current is the largest contributor to the dark current at biases below one volt.

The $\mathrm{GaAs}$ and $\mathrm{Al}_{\mathrm{x}} \mathrm{Ga}_{1-\mathrm{x}} \mathrm{As}$ layers were grown on a two-inch liquid-encapsulatedCzochralski (LEC) (100)-GaAs substrate in a Varian GEN II molecular beam epitaxy (MBE) system at Purdue University. The source materials consisted of elemental gallium, arsenic, and aluminum, with beryllium and silicon used as $\mathrm{p}$ - and n-type dopants, respectively. The layers were grown at a substrate temperature of $600^{\circ} \mathrm{C}$ (the oxide 
desorption temperature was $580^{\circ} \mathrm{C}$ ). A superlattice layer consisting of 20 periods of $28 \AA$ $\mathrm{Al}_{0.33} \mathrm{Ga}_{0.67} \mathrm{As}$ barriers and $31 \AA$ GaAs wells was incorporated in the film structure to reduce diffusion of impurities from the substrate into the growing film [12]. Reflection high-energy electron diffraction patterns were used to monitor the growth rate and growth conditions. Each of two gallium furnaces produced a flux corresponding to a growth rate of $0.5 \mu \mathrm{m} / \mathrm{hr}$, for a net growth rate of $1.0 \mu \mathrm{m} / \mathrm{hr}$. The $\mathrm{As}_{4}$ to total $\mathrm{Ga}$ beam equivalent pressure measured with an ion-gauge in the substrate growth position was 27.

In order to separate the current components, the processed devices consisted of squares with areas ranging from $2.5 \times 10^{-5}$ to $0.01 \mathrm{~cm}^{2}$ and perimeter-to-area (P/A) ratios varying from 40 to $800 \mathrm{~cm}^{-1}$. The masking levels also included devices necessary to study the effect of crystallographic orientation on perimeter recombination [13], and $0.5 \mathrm{~cm} \mathrm{x} 0.5$ $\mathrm{cm}$ solar cells. The processing was as follows. First, a back ohmic contact was formed by alloying indium at $350^{\circ} \mathrm{C}$ for 1 minute because a non-indium wafer mount was used during the MBE growth. Front metallization lift-off patterns were then defined, Ti/Au was electron-beam evaporated to form non-alloyed ohmic contacts, and the photoresist was dissolved in acetone to remove the excess metal. Following the metal deposition, mesas were defined using conventional photolithography and etched in a $25^{\circ} \mathrm{C}$ methanol: $\mathrm{H}_{2} \mathrm{O}_{2}: \mathrm{H}_{2} \mathrm{O}: \mathrm{H}_{3} \mathrm{PO}_{4}$ 3:1:1:1 solution for $1 \mathrm{~min} 15 \mathrm{sec}$. The etch rate was approximately two microns per minute making this etch suitable for mesa isolation.

\section{Measured I-V Characteristics}

The current versus voltage characteristics of a $64 \mu \mathrm{m}$ by $64 \mu \mathrm{m}$ diode at $25.8^{\circ} \mathrm{C}$ are displayed in Fig. 4 along with the diode's ideality factor versus voltage. To characterize this device, we seek to quantify the bias-dependent contributions of perimeter and bulk recombination to the current. Another objective is to determine whether the drop in ideality factor for $V_{A} \geq 0.9 \mathrm{~V}$ is due to perimeter or bulk recombination.

The bulk and perimeter recombination currents were examined by performing detailed measurements of the diode current-voltage characteristics for diodes with several $\mathrm{P} / \mathrm{A}$ ratios. The ideality factors and saturation current densities were separated by using a plot of the total current density versus $\mathrm{P} / \mathrm{A}$ ratio at incremental voltage steps as shown in Fig. 5. The total current in the diode may be written as the sum of the bulk and perimeter current components, with the perimeter current scaling as P/A:

$$
\frac{I}{A}=J_{o n B}\left(e^{q V A / n_{B} k T}-1\right)+J_{o n P}\left(e^{q V_{A} / n_{p k} T}-1\right) \frac{P}{A} .
$$




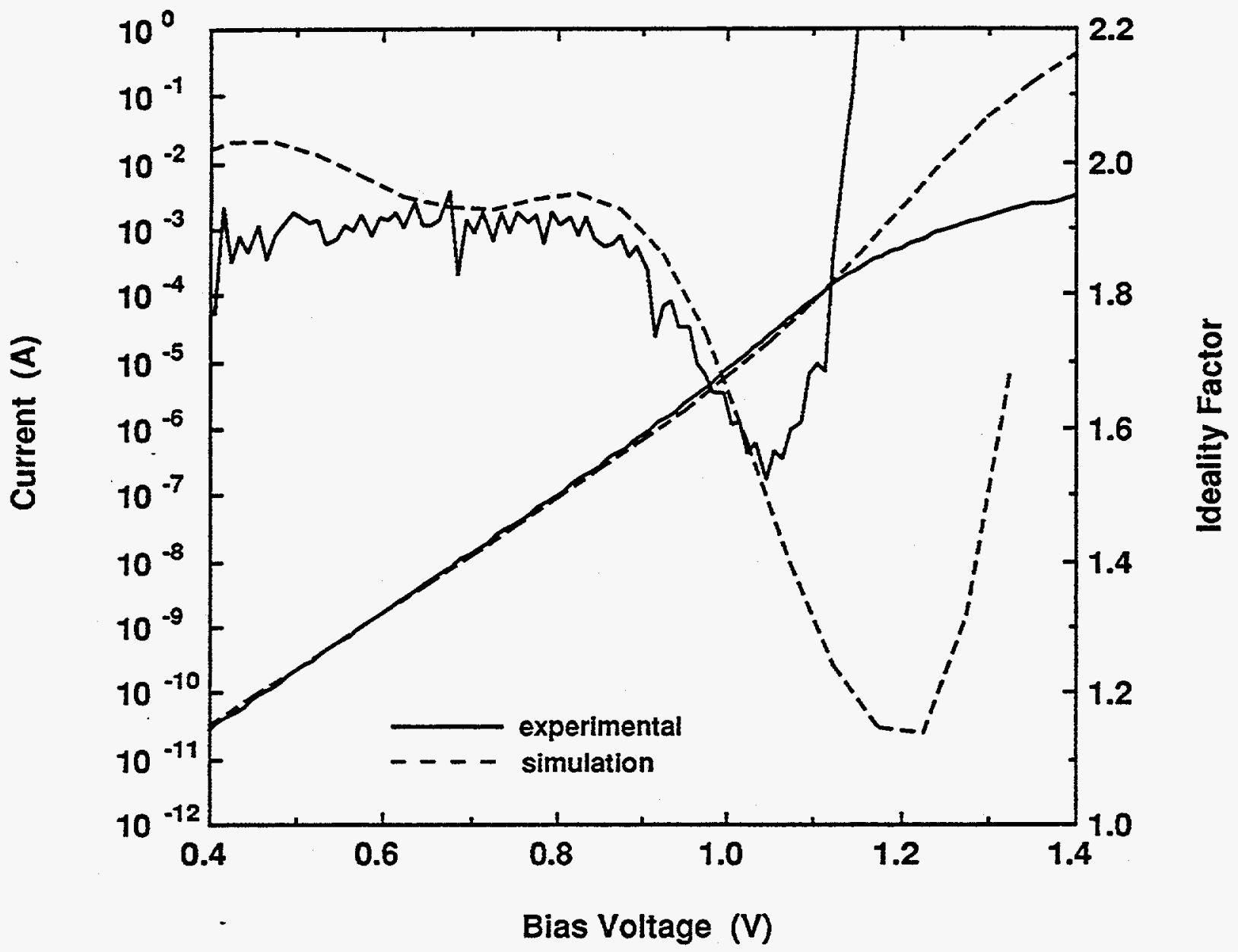

Fig. 4. Experimental and simulated current-voltage characteristics and current ideality factors of heteroface GaAs diode shown in Fig. 2. Simulation parameters are $S=4 \times 10^{5} \mathrm{~cm} / \mathrm{s}$, surface trap concentration of $5 \times 10^{12} \mathrm{~cm}^{-2}$, and carrier lifetimes of $1 \mathrm{nsec}$. 
As shown in Fig. 5, (3) accurately describes our devices. The slope of I/A versus $V_{A}$ is related to the perimeter current and the intercept to the bulk current. For this $64 \mu \mathrm{m}$ by 64 $\mu \mathrm{m}$ diode, the perimeter current dominates for applied biases up to 1.0 volt.

For a small voltage step $\Delta V=V_{2}-V_{1}$, the slopes of two adjacent lines may be used to extract the perimeter saturation current density and ideality factor:

$$
\begin{aligned}
& \text { slope }_{1}=J_{\text {onP } P}\left(\begin{array}{l}
e^{q V_{1} / n_{p} k T}-1 \\
\text { slope }_{2}=J_{\text {onP } P}\left(e^{q V_{2} / n_{p} k T}-1\right.
\end{array}\right) .
\end{aligned}
$$

At each voltage, the slope is determined from a simple least-squares fit to the experimental data. Equation (4) is then just a system of two equations in two unknowns which is solved for $\mathrm{J}_{\mathrm{onP}}$ and np. Similarly, the bulk saturation current density and ideality factor may be determined from the intercepts of the lines.

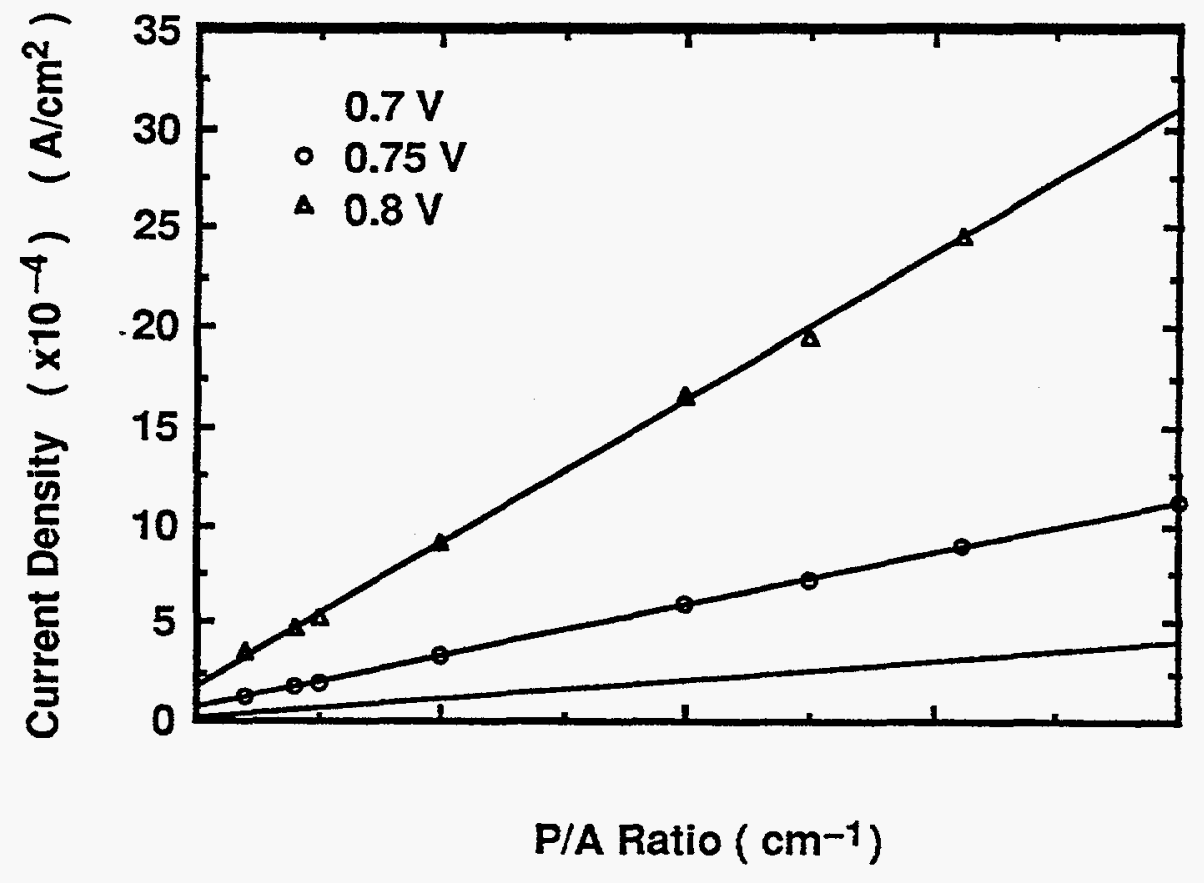

Fig. 5. Diode current density versus $\mathrm{P} / \mathrm{A}$ ratio at $0.7,0.75$, and 0.8 volts. 
The ideality factors vs. bias for the total, perimeter, and bulk currents are displayed in Fig. 6a. The bulk current ideality factor shows a strong bias dependence, varying from $\mathrm{n} \approx 1.8$ at low bias where recombination in the junction space charge region dominates to $\mathrm{n}$ $\approx 1$ for high applied biases where recombination in the quasi-neutral regions dominates (for biases above 1 volt, the series resistance becomes important and ideality factors can not be extracted). The perimeter ideality factor shows a similar, though weaker, bias dependence. Finally, Fig. $6 \mathrm{~b}$ shows that the perimeter current dominates for $\mathrm{V}_{\mathrm{A}} \leq 0.9 \mathrm{~V}$, above which bulk recombination becomes important.

The experimentally observed bulk current is well-described by conventional $\mathrm{p} / \mathrm{n}$ junction theory. The bias-dependent ideality factor for the perimeter current was not predicted by Henry et al. [9] but has been discovered by numerical simulations [10]. In the next section we employ numerical simulation to examine the physics of perimeter recombination.

\section{Model Description}

The two-dimensional device simulator, PUPHS2D, [14] was modified to include surface states and Fermi level pinning using an approach similar to [11]. The model is based on a drift-diffusion description of carrier transport and treats $\mathrm{Al}_{\mathrm{x}} \mathrm{Ga}_{1-\mathrm{x}} \mathrm{As}$ heterostructures. A bandgap narrowing model for heavily-doped p-type GaAs based on the data of Klausmeier-Brown [15] is present, but was not used in the computations since the diodes were designed to suppress injection currents. Surface recombination is modeled with SRH recombination through deep level traps. We assume two discrete trap levels, donor-like and acceptor-like. If the surface densities (per $\mathrm{cm}^{2}$ ) of these traps are denoted by $\mathrm{N}_{\mathrm{TD}}$ and $\mathrm{N}_{\mathrm{TA}}$, then the ionized trap surface densities $\mathrm{N}_{\mathrm{TD}}{ }^{+}$and $\mathrm{N}_{\mathrm{TA}}{ }^{-}$are given by [16]:

$$
\begin{aligned}
& \frac{N_{T D}^{+}}{N_{T D}}=\frac{S_{n d} n_{t d}+S_{p d} p_{s}}{S_{n d}\left(n_{s}+n_{t d}\right)+S_{p d}\left(p_{s}+p_{t d}\right)} \\
& \frac{N_{T A}^{-}}{N_{T A}}=\frac{S_{n a} n_{s}+S_{p a} p_{t a}}{S_{n a}\left(n_{s}+n_{t a}\right)+S_{p a}\left(p_{s}+p_{t a}\right)},
\end{aligned}
$$

where $\mathrm{p}_{s}$ and $\mathrm{n}_{\mathrm{s}}$ are the surface hole and electron concentrations, $\mathrm{S}_{\mathrm{nd}}, \mathrm{S}_{\mathrm{pd}}, \mathrm{S}_{\mathrm{na}}$ and $\mathrm{S}_{\mathrm{pa}}$ are the electron and hole surface recombination velocities for donor-like and acceptor-like traps, and $n_{t d}, p_{t d}, n_{t a}$, and $p_{t a}$ are the electron and hole concentrations that would exist if the Fermi level were pinned at the donor or acceptor levels. For example, 


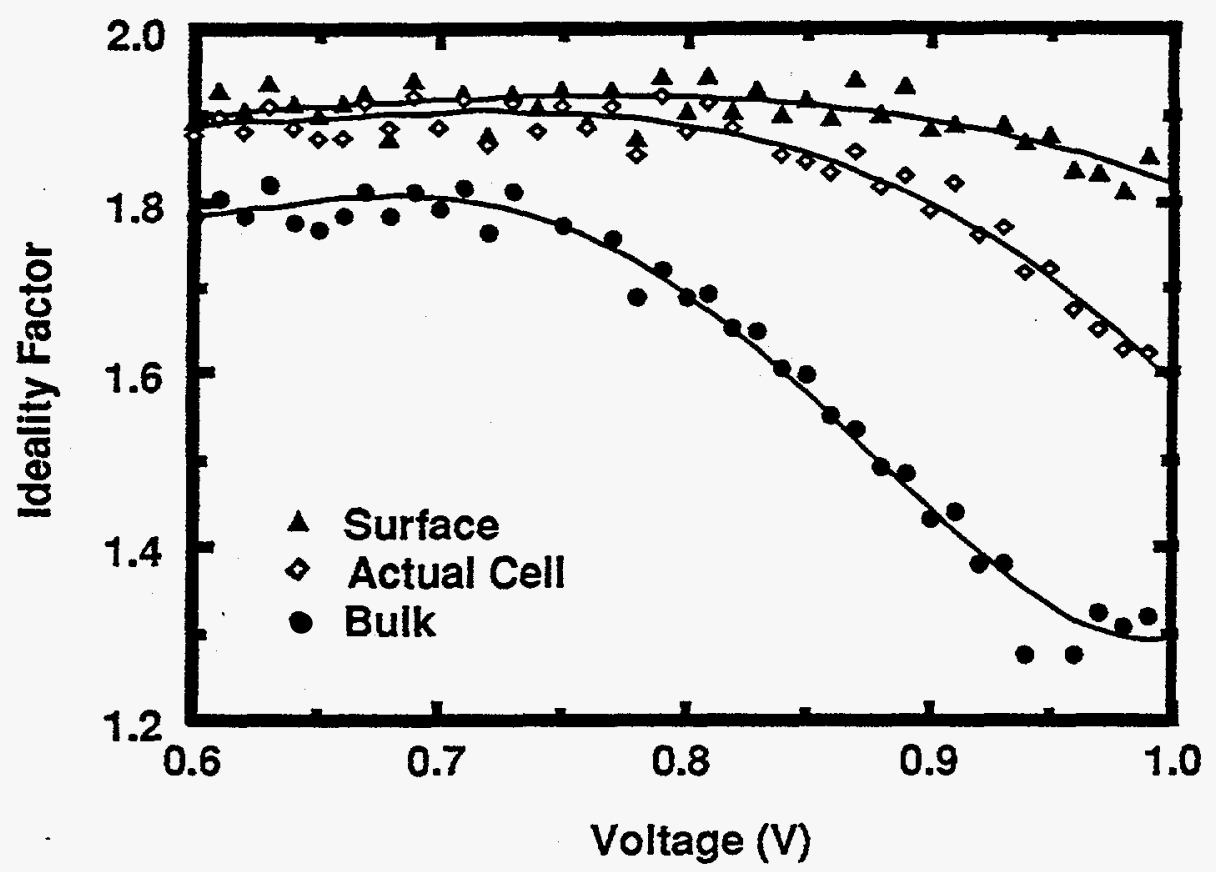

Fig. 6a. Diode ideality factor versus applied bias for the perimeter, bulk, and actual cell.

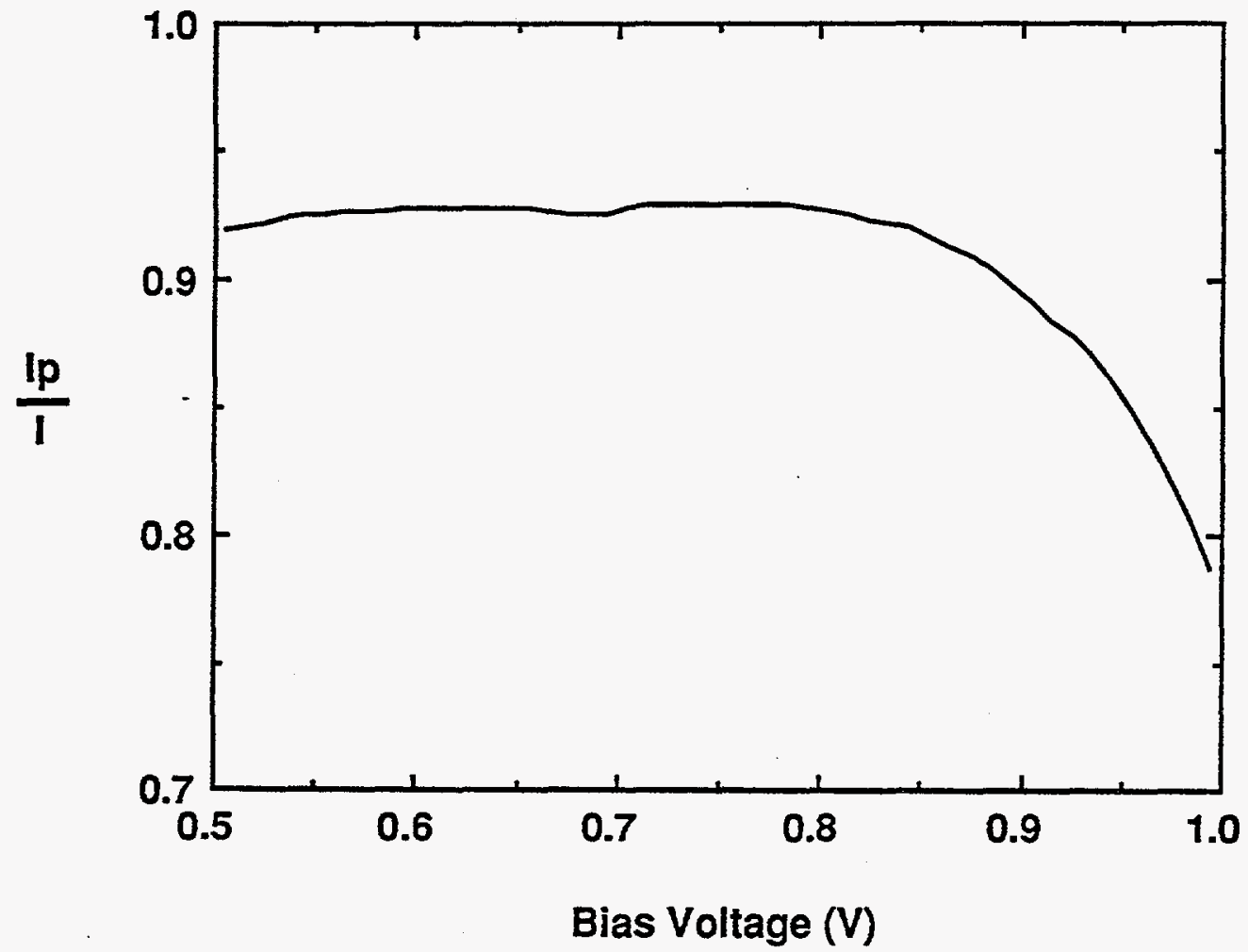

Fig. 6b. Ratio of perimeter current to total current as a function of bias in a cell with a perimeter-to-area ratio of $600 \mathrm{~cm}^{-1}$. 


$$
n_{t d}=n_{i e} e^{\left(E_{D T}-E_{i}\right) / k T},
$$

where $E_{D T}$ is the energy level of the donor-like traps. The effect of the charge of the ionized traps alters the boundary condition to the Poisson equation (obtained from applying Gauss' law about a small box at the semiconductor-free space interface) according to:

$$
\nabla V \cdot \hat{n}=\frac{q\left(N_{T D}^{+}+N_{T A}^{-}+N_{F}\right)}{\varepsilon_{S}},
$$

where $\hat{n}$ is a unit vector normal to the surface, $\varepsilon_{s}$ is the semiconductor dielectric constant at the surface, and $\mathrm{qN}_{\mathrm{F}}$ is the fixed charge at the surface. Note that while $\mathrm{N}_{\mathrm{F}}$ is constant, $\mathrm{N}_{\mathrm{TD}}{ }^{+}$and $\mathrm{N}_{\mathrm{TA}}{ }^{-}$will vary with bias. The surface recombination rate is then given by:

$$
R_{s}=\frac{n_{s} p_{s}-n_{i e}^{2}}{\frac{1}{S_{p d}}\left(n_{s}+n_{t d}\right)+\frac{1}{S_{n d}}\left(p_{s}+p_{t d}\right)}+\frac{n_{s} p_{s}-n_{i e}^{2}}{\frac{1}{S_{p a}}\left(n_{s}+n_{t a}\right)+\frac{1}{S_{n a}}\left(p_{s}+p_{t a}\right)}
$$

The first term represents recombination at the donor-like surface traps and the second recombination at the acceptor-like traps.

While the model is formulated in terms of two discrete surface trap energy levels, it was found that for traps located near midgap [1], there is little practical difference between two trap levels off midgap and one trap level located at midgap. All simulation results reported in this chapter were therefore performed with equal concentrations of acceptor-like and donor-like traps located at midgap. In addition, equal surface recombination velocities were assumed throughout.

\section{Simulation Results}

\section{Current-Voltage Characteristics}

The terninal characteristics of the GaAs $\mathrm{p} / \mathrm{n}$ diodes described in Section II were computed with the numerical simulation program in order to study the perimeter recombination mechanism. The resultant current-voltage characteristics are compared to the measured results in Fig. 4. Bulk lifetimes of $1 \mathrm{~ns}$ were used in the calculation. The surface parameters were a total surface trap concentration of $5 \times 10^{12} \mathrm{~cm}^{-2}$, and surface recombination velocities $S_{n}=S_{p}=4 \times 10^{5} \mathrm{~cm} / \mathrm{s}$, where $S_{n}=S_{n d}+S_{n a}$ and similarly for $S_{p}$. The corresponding capture coefficients (e.g. $c_{n d}=S_{n d} / N_{T D}$ ) are then $8 \times 10^{-8} \mathrm{~cm}^{3} / \mathrm{s}$. It can be seen in Fig. 4 that the simulated current-voltage behavior using these parameters 
reproduces the actual data very well until high bias voltages are applied, when the actual device exhibits higher series resistance than the model predicts. It should be mentioned that the surface model contains eight adjustable parameters: $S_{n d}, S_{p d}, S_{n a}, S_{p a}, N_{T D}, N_{T A}$, and the trap energy levels. It is for this reason that we choose the simplest possible model by assuming equal recombination velocities, trap concentrations, and energy levels positioned at midgap. We demonstrate later that this simple model accurately describes both the dark and illuminated characteristics of these diodes.

The perimeter current ideality factor exhibits an inclination toward an $n \approx 1$ ideality factor, which is shown in Fig. 7, a plot of the experimentally observed and simulated perimeter current ideality factor versus bias voltage. The simulation shows a strong drop in the perimeter ideality factor above $1 \mathrm{~V}$ of bias, reaching a minimum value of about 1.5 before rising due to series resistance. A similar strong bias dependence to the perimeter current ideality factor has been reported by Tiwari and colleagues [10]. In Sec. V we discuss the physical origin of the bias dependence.

\section{Internal Quantum Efficiency vs. Wavelength}

As will be discussed in Section $\mathrm{V}$, the choice of surface recombination velocity and surface state density used to fit the measured I-V characteristic is not unique. The model was further tested by examining the diode's photocurrent response. For this experiment, the passivating $\mathrm{Al}_{\mathrm{x}} \mathrm{Ga}_{1-\mathrm{x}} \mathrm{As}$ heteroface was removed from the $\mathrm{p}^{+}$layer by chemical etching. Figure 8 shows the measured internal quantum efficiency versus wavelength. For short wavelengths, carriers are generated near the $\mathrm{p}^{+}$surface, where they recombine leading to a low quantum efficiency. Also shown in Fig. 8 is the simulated quantum efficiency vs. wavelength using the same recombination parameters employed to match the dark I-V characteristics. We observe that the simple model can therefore reproduce both the dark and illuminated characteristics of these devices with $S=4 \times 10^{5} \mathrm{~cm} / \mathrm{s}$ and $N_{T D}=5 \times 10^{12}$ $\mathrm{cm}^{-2}$. 


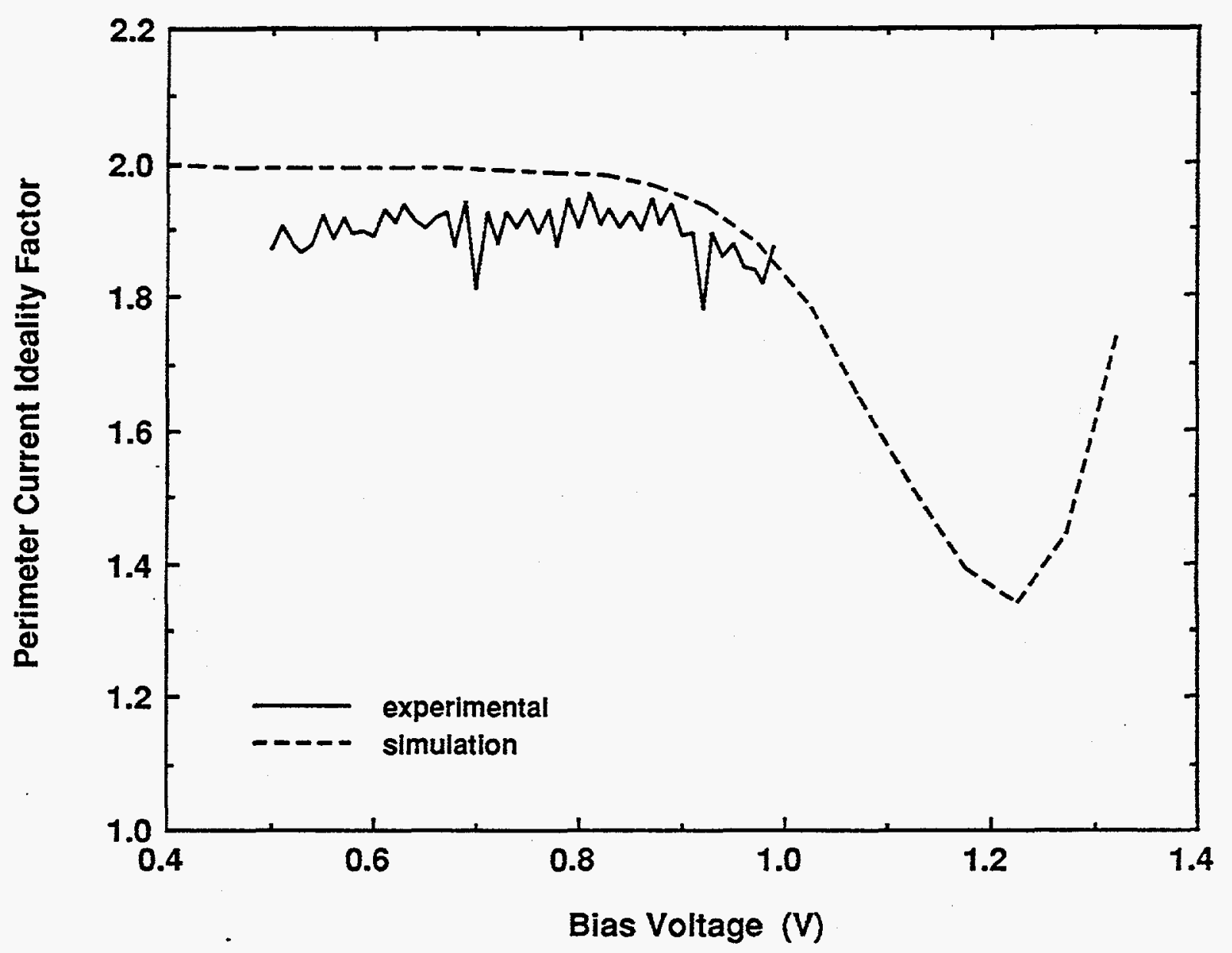

Fig. 7. Perimeter current ideality factor in experimental and simulated heteroface $\mathrm{GaAs}$ diodes as a function of forward bias voltage. A perimeter recombination velocity of $4 \times 10^{5} \mathrm{~cm} / \mathrm{s}$ and a trap concentration of $5 \times 10^{12}$ $\mathrm{cm}^{-2}$ were used in the simulation. Reduced $\mathrm{n}$-factor at higher biases is due to recombination of injected carriers at the surface. 


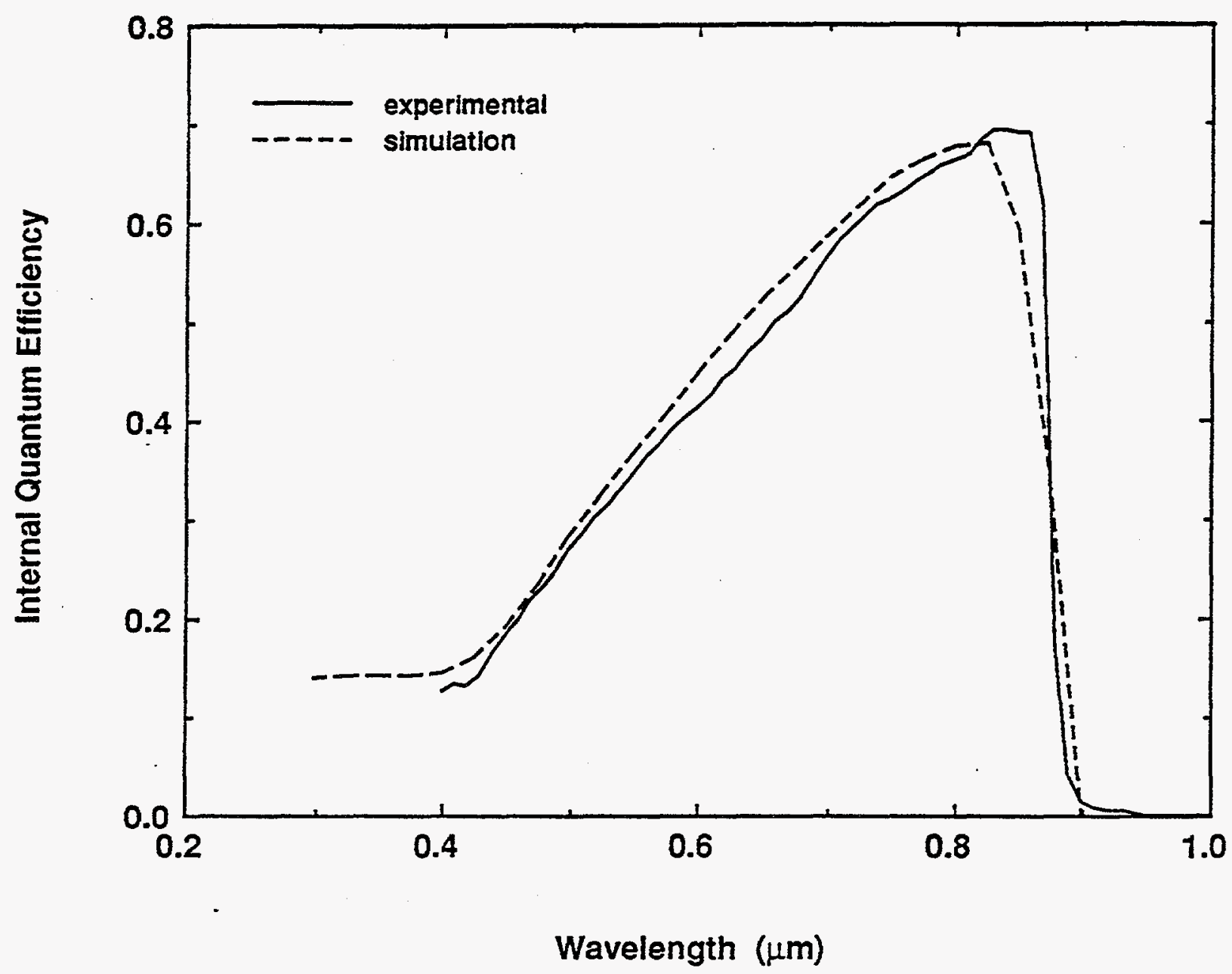

Fig. 8. Experimental and simulated quantum efficiency within a high-efficiency GaAs heteroface solar cell with the front heteroface removed. 


\section{Discussion}

\section{Current-Voltage Characteristics}

Both the measured and simulated results show that the perimeter current has a nearly constant ideality factor of $\mathrm{n} \approx 2$ for low biases but that it decreases for high applied biases. For low biases, the theory of Henry et al. [9] should apply. Figure 3 shows, however, that the perimeter recombination occurs primarily where the junction spacecharge region intersects the surface- not in the surface channels outside the junction depletion region as assumed by Henry et al. From (2) with $\mathrm{s}_{\mathrm{o}}=4 \times 10^{5} \mathrm{~cm} / \mathrm{s}$, we estimate the effective width for surface recombination as $L_{s} \approx 350 \AA$ under a forward bias of 0.6 volts. This should be compared with the effective width for recombination in the bulk junction space-charge region which is estimated from ( $1 \mathrm{~b})$ as $\mathrm{W}_{\text {eff }} \approx 32 \AA$ and the junction depletion region width which is $\approx 760 \AA$. The charged surface states at the perimeter reduce the electric field, $\varepsilon_{y}$ which, according to $(1 \mathrm{~b})$ increases the width over which recombination occurs.

Both the measured results and the simulation show that the perimeter current ideality factor decreases under high applied bias. Figure 9 is a plot of the normalized recombination rate versus position along the perimeter. For low and moderate applied biases, perimeter recombination occurs where the junction depletion region intersects the perimeter. The ideality factor is about 2 , similar to the bulk space-charge recombination current, but the surface states alter the electrostatics which broadens the recombination peak. As the bias increases, perimeter recombination spreads to the surface channels outside the junction space-charge region. As Tiwari observed, under such conditions, the perimeter current ideality factor decreases and approaches unity [10].

Previous workers have emphasized the role of carrier injection in the surface channels. Although the barrier height at the surface $\left(V_{b i s}\right.$ as defined in Fig. 2$)$ is reduced by the band bending at the surface, majority carriers enter the channel through the bulk regions where they must surmount an additional barrier. So it is not clear that injection in the surface channel should dominate. To investigate the importance of injection in the surface channel for these diodes, it is necessary to establish where the carriers that recombine in the channel originate. Figure 10 is a plot of the electron current flow within the diode under a bias of 1.4 volts. The confinement of the injected minority carrier electrons by the heteroface, and their consequent lateral diffusion to the perimeter are readily observed. For these diodes, the carriers recombining within the surface channel are primarily those injected into the bulk quasi-neutral region which then diffuse to the perimeter, injection in the surface channel does not play an important role. 

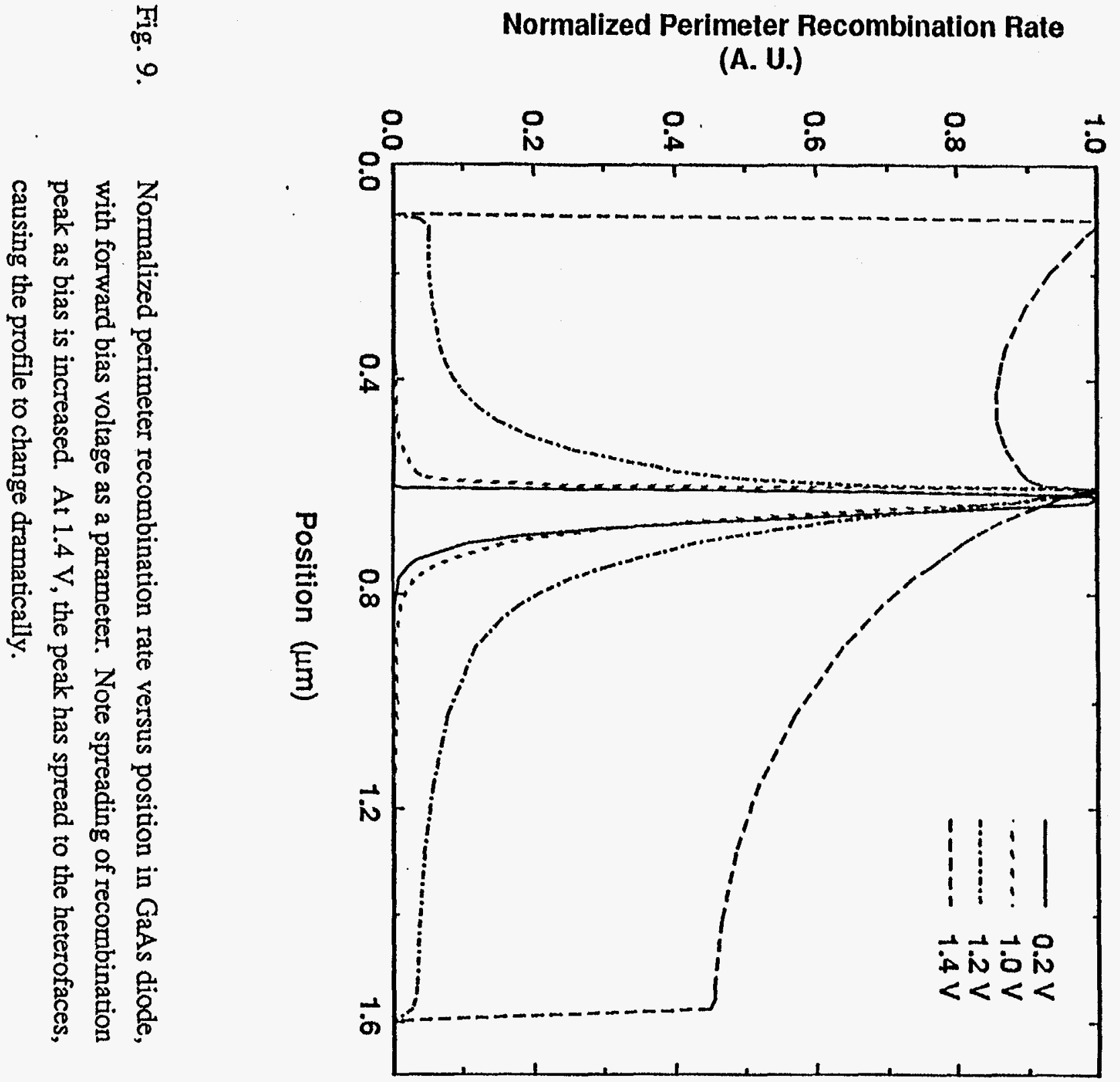


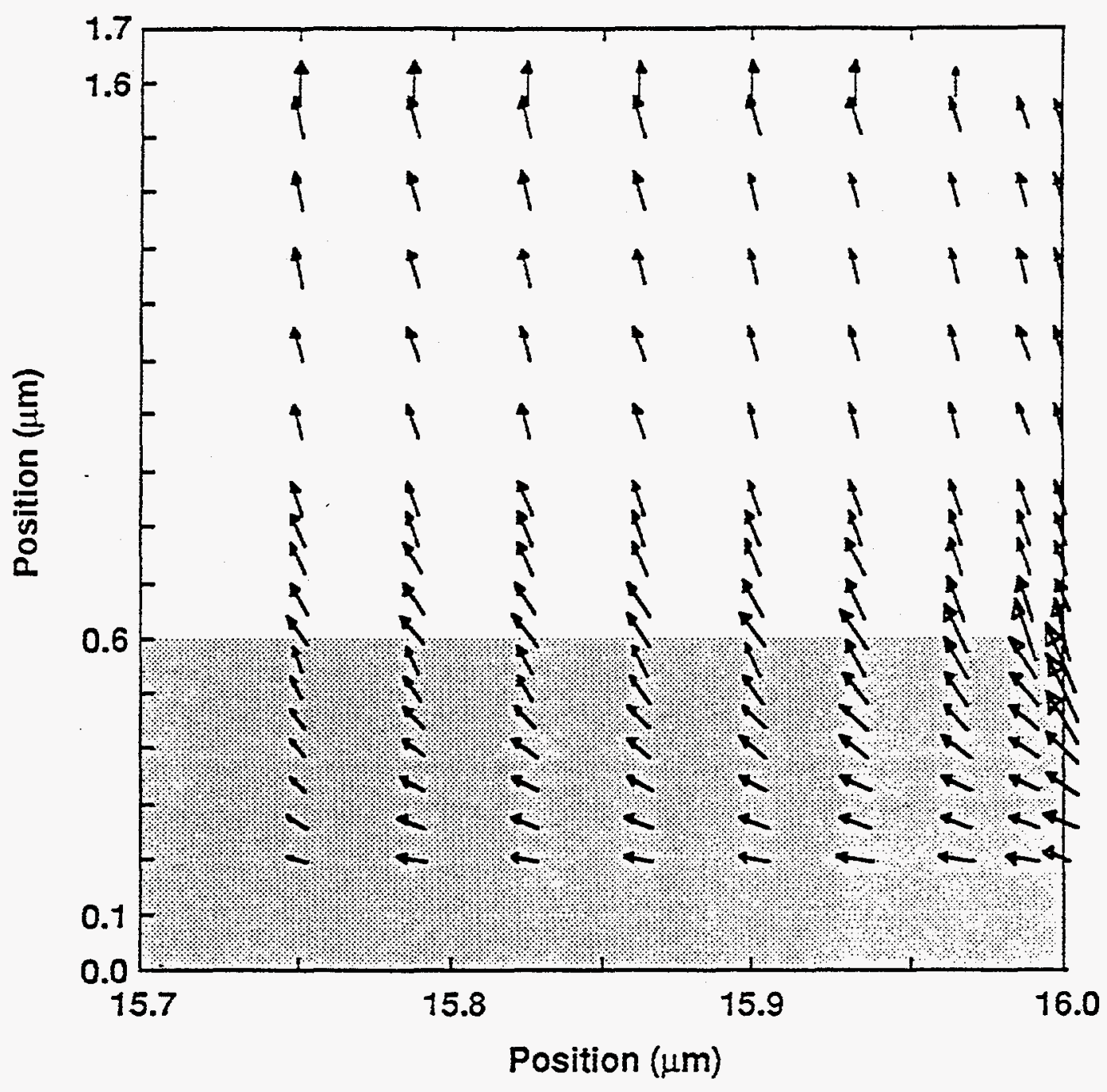

Fig. 10. Electron current flow pattern within the heteroface diode at a bias of $1.4 \mathrm{~V}$. The shading indicates the $\mathrm{p}^{+}$region of the diode, and the size of the arrows indicates the relative magnitude of the current. 
As mentioned previously, the choice of $S$ and $\mathrm{N}_{\mathrm{T}}$ to match the measured I-V characteristics is not unique. It is even possible to match the data, including the biasdependent perimeter current ideality factor, with $\mathrm{N}_{\mathrm{T}}=0$ if $\mathrm{S}$ is increased to $10^{7} \mathrm{~cm} / \mathrm{s}$. This is another indication that conduction in the surface channels does not play an important role. When $\mathrm{N}_{\mathrm{T}}=0$, the electric field where the junction intersects the perimeter is identical to that in the bulk, so $L_{s}=W_{\text {eff. }}$ As the surface state density is increased, the electric field is reduced, which broadens the recombination peak so that a smaller surface recombination velocity is required. It is not possible to identify a unique $S$ and $N_{T}$ from the measured dark I-V characteristics, but additional information on surface recombination is available by examining the measured internal quantum efficiency versus wavelength.

\section{Internal Quantum Efficiency vs. Wavelength}

When the passivating AlGaAs layer is removed, the short-wavelength internal quantum efficiency is sensitive to recombination at the exposed surface of the $\mathrm{p}^{+}$layer. As demonstrated by Fig. 8, the simple model with $S=4 \times 10^{5} \mathrm{~cm} / \mathrm{s}$ and $N_{\mathrm{T}}=5 \times 10^{12} \mathrm{~cm}^{-2}$ does a good job of reproducing the measured photocurrent versus wavelength as well as the measured dark I-V characteristic. Again, the choice of $N_{T}$ and $S$ are not unique, but we find that with $\mathrm{N}_{\mathrm{T}}=10^{13} \mathrm{~cm}^{-2}$ the simulation underestimates the short wavelength quantum efficiency, even with $S=0$. For this case, the band bending at the surface produces a potential well that confines the photogenerated carriers. With $\mathrm{N}_{\mathrm{T}}=0$ it is still possible to match the measured quantum efficiency, but $S$ must be increased to $10^{7} \mathrm{~cm} / \mathrm{s}$.

Internal quantum efficiency measurements are routinely analyzed by solving a minority carrier diffusion equation ignoring the space-charge layer at the surface [17]. In this case, the surface recombination velocity is really an effective value which relates the current density to the excess minority carrier concentration by:

$$
I_{n}\left(x_{1}\right)=q S_{\text {eff }} \Delta n\left(x_{1}\right) \text {. }
$$

When interpreting the measured quantum efficiency for devices with exposed GaAs surfaces, values of $S_{\text {eff }} \approx 10^{7} \mathrm{~cm} / \mathrm{s}$ are commonly obtained [7]. Evidently, the band bending caused by the charged states along with $S=4 \times 10^{5} \mathrm{~cm} / \mathrm{s}$ produces an effective surface recombination velocity of $\approx 10^{7} \mathrm{~cm} / \mathrm{s}$. This hypothesis can be tested by examining the numerical simulation results. By evaluating the excess electron concentration and the electron current at the boundary of the surface space-charge layer, we deduce $S_{\text {eff }}=$ $1.1 \times 10^{7} \mathrm{~cm} / \mathrm{s}$. So a surface state density of $5 \times 10^{12} \mathrm{~cm}^{-2}$ and $\mathrm{S}=4 \times 10^{5} \mathrm{~cm} / \mathrm{s}$ reproduces 
the measured quantum efficiency of our diodes and produces the effective recombination velociry commoniy observed in practice [7].

\section{Conclusion}

GaAs heteroface diodes have been studied experimentally and with numerical modeling in order to determine the mechanisms responsible for surface and perimeter recombination. An experimental technique was described which allows extraction of the perimeter and bulk current components. A surface model which treats Fermi level pinning by $S R H$ recombination through deep level traps was used and extensively compared to the experimental data for the purpose of verifying the model and quantifying the model parameters. A density of $5 \times 10^{12} \mathrm{~cm}^{-2}$ traps located at midgap with surface recombination velocities of $4 \times 10^{5} \mathrm{~cm} / \mathrm{s}$ were found to reproduce the experimental data very well. Both the dark current versus voltage and the internal quantum efficiency versus wavelength are well described by this simple model.

For the GaAs homojunction diodes investigated, we found that the diode current under moderate forward bias was controlled by recombination along the perimeter. Most of the recombination occurs where the junction space-charge region intersects the perimeter, and it results in an ideality factor of $\approx 2$. Both the measured data and the computer model show that the ideality factor of the perimeter current decreases under high forward bias. The computer modeling results demonstrate that the decrease in ideality factor is caused by carriers injected in the bulk regions diffusing to the perimeter. For these devices, there appears to be little injection of carriers into the surface channel induced by Fermi level pinning. Computer modeling experiments uncovered no distinctive features in the current-voltage characteristic which could be attributed to Fermi level pinning. We found that the dark and illuminated characteristics could even be modeled by ignoring the charge on the surface states and employing an effective surface recombination velocity of $\approx$ $10^{7} \mathrm{~cm} / \mathrm{s}$. In conclusion, we have demonstrated that a simple, one-level model of the GaAs surface can account for the measured characteristics of GaAs homojunction diodes. We also demonstrated that the surface channels introduce no distinctive features in the simulated characteristics of such devices, so the common practice of ignoring the surface state charge and using an effective surface recombination velocity of $=10^{7} \mathrm{~cm} / \mathrm{s}$ can be justified. 


\section{Chapter 1 References}

[1] W. E. Spicer and S. J. Eglash, "Fundamental studies of interfaces: The unified defect model and its application to GaAs integrated circuits," in VLSI Electronics Microstructure Science Volume 10, Einspruch and Bauer, Eds. : Academic Press, Inc., 1985.

[2] P. D. DeMoulin, S. P. Tobin, M. S. Lundstrom, M. S. Carpenter, and M. R. Melloch, "Influence of perimeter recombination of high-efficiency GaAs p/n heteroface solar cells," IEEE Electron Device Lett., vol. EDL-9, no. 8, pp. 368370, Aug. 1988.

[3] P. M. Asbeck, D. L. Miller, R. J. Anderson, L. D. Hou, R. Deming, and F. Eisen, "Nonthreshold logic ring oscillators implemented with GaAs/(GaAl)As heterojunction bipolar transistors," IEEE Electron Device Lett., vol. EDL-5, no. 5, pp. 181-183, May 1984.

[4] Y. S. Hiraoka, J. Yoshida, and M. Azuma, "Two-dimensional analysis of emittersize effect on current gain for GaAlAs/GaAs HBT's," IEEE Trans. Electron Devices, vol. ED-34, no. 4, pp. 721-725, Apr. 1987.

[5] M. T. Schmidt, Q: Y. Ma, D. V. Podlesnik, R. M. Osgood, E. S. Yang, "Chemically modified GaAs Schottky barrier variation,"J. Vac. Sci. Technol., vol. B7, no. 4, pp. 980-985, Jul. 1989.

[6] E. Yablonovitch, C. J. Sandroff, R. Bhat, and T. Gmitter, "Nearly ideal electronic properties of sulfide coated GaAs surfaces," Appl. Phys. Lett., vol. 51, no. 6, pp. 439-441, Aug. 1987.

[7] L. D. Partain, M. S. Kuryla, L. M. Fraas, P. S. McLeod, and J. A. Cape, "A new sequentially etched quantum-yield technique for measuring surface recombination velocity and diffusion lengths of solar cells," J. Appl. Phys., vol. 61, no. 11, pp. 5150-5158, Jun. 1987.

[8] C. T. Sah, R. N. Noyce, and W. Shockley, "Carrier generation and recombination in $\mathrm{p}-\mathrm{n}$ junctions and $\mathrm{p}-\mathrm{n}$ junction characteristics," Proc. IRE, vol. 45, pp. 12281243, Sep. 1957.

[9] C. H. Henry, R. A. Logan, and F. R. Merrit, "The effect of surface recombination on current in $\mathrm{Al}_{\mathrm{x}} \mathrm{Ga}_{1-\mathrm{x}} \mathrm{As}$ heterojunctions," J. Appl. Phys., vol. 49, no. 6, pp. 3530-3542, Jun. 1978 .

[10] S. Tiwari, D. J. Frank, and S. L. Wright, "Surface recombination in GaAlAs/GaAs heterostructure bipolar transistors," J. Appl. Phys., vol. 64, no. 10, pp. 50095012, Nov. 1988. 
[11] Y. S. Hiraoka and J. Yoshida, "Two-dimensional analysis of the surface recombination effect on current gain for GaAlAs/GaAs HBT's," IEEE Trans. Electron Devices, vol. EDL-35, no. 7, pp. 857-862, Jul. 1988.

[12] K. L. Tan, M. S. Lundstrom, and M. R. Melloch, "Effect of impurity trapping on the capacitance-voltage characteristics of $n-G a A s / N-A l G a A s$ heterojunctions," Appl. Phys. Lett., vol. 48, no. 6, pp. 428-430, Feb. 1986.

[13] T. B. Stellwag, M. R. Melloch, M. S. Lundstrom, M. S. Carpenter, and R. F. Pierret, "Orientation-dependent perimeter recombination in GaAs diodes," Appl. Phys. Lett., vol. 56, no. 17, pp. 1658-1660, Apr. 1990.

[14] P. E. Dodd, "Simulation of heterojunction bipolar transistors in two dimensions," Purdue University, School of Electrical Engineering Tech. Rept. TR-EE 89-68, Dec. 1989.

[15] M. E. Klausmeier-Brown, M. R. Melloch, and M. S. Lundstrom, "Transistorbased measurements of electron injection currents in p-type GaAs doped $10^{18}$ to $10^{20} \mathrm{~cm}^{-3}$," Appl. Phys. Lett., vol. 56, no. 2, pp. 160-162, Jan. 1990.

[16] R. F. Pierret, Advanced Semiconductor Fundamentals, Addison-Wesley, Reading, Mass., 1987.

[17] H. J. Hovel and J. M. Woodall, "Theoretical and experimental evaluations of $\mathrm{Ga}_{1-\mathrm{x}} \mathrm{Al}_{\mathrm{x}} \mathrm{As}-\mathrm{GaAs}$ solar cells," in Proceedings of the 10th IEEE Photovoltaic Specialists Conference, pp. 25-30, Nov. 1973. 


\section{CHAPTER 2}

\section{$\mathrm{As}_{2} \mathrm{~S}_{3}$ PASSIVATION OF GaAs SURFACES}

\subsection{INTRODUCTION}

In the last few years it has been shown that chemical treatments of GaAs surfaces with inorganic sulfides can produce dramatic modifications of the surface electrical properties [1-6]. The gains of non-self-aligned heterojunction bipolar transistors (HBTs) have been shown to increase by 60 -fold with treatment of the emitter base junction with $\mathrm{Na}_{2} \mathrm{~S} \cdot 9 \mathrm{H}_{2} \mathrm{O}$ [1,2]. Reduction in edge recombination currents have been observed with $\mathrm{Na}_{2} \mathrm{~S} \cdot 9 \mathrm{H}_{2} \mathrm{O}$ and ammonium sulfide treatment of GaAs pn homojunction solar cells [3]. These reductions in perimeter currents can be attributed to the reduction in surface recombination of the GaAs surface after the inorganic sulfide treatment [6]. The chemical nature of one of these inorganic sulfide treatments, ammonium sulfide, has been investigated with X-ray photoelectron spectroscopy (XPS) [8-10]. The XPS studies found that the ammonium sulfide treatment removes surface oxides and terminates the GaAs surface with about a monolayer of sulfur. Since the ammonium sulfide chemically modified GaAs surface is terminated with just a monolayer of sulfur, it is not surprising that the surface eventually degrades back to its initial electrical characteristics due to reoxidation of the underlying GaAs [9]. Recently, Yablonovitch et al. [11] have developed a sulfide chemical treatment which leaves the GaAs surface coated with an amorphous $\mathrm{As}_{2} \mathrm{~S}_{3}$ layer. This $A s_{2} S_{3}$ chemical treatment resulted in a 100 -fold reduction in perimeter current for conventional double heterostructure lasers with no degradation after four months. This absence of degradation was attributed to the impermeability of the $\mathrm{As}_{2} \mathrm{~S}_{3}$ glass which prevents oxygen from diffusing to the GaAs surface.

We have previously shown that perimeter recombination can control the $2 \mathrm{kT}$ current in GaAs solar cells as large as $2 \mathrm{~cm} \times 2 \mathrm{~cm}$ [12]. Perhaps as important is that the characteristics of small area devices which are used for diagnostics are dominated by perimeter recombination. Therefore a permanent passivation of GaAs surfaces would have benefits for GaAs solar cells. In this chapter we report our investigations of the passivation of pn homojunction GaAs diodes and self- aligned HBTs with the $\mathrm{As}_{2} \mathrm{~S}_{3}$ chemical treatment. 


\section{$2.2 \mathrm{As}_{2} \mathrm{~S}_{3}$ PASSIVATION OF GaAs pn JUNCTIONS}

The AlGaAs/GaAs diode structure used in this experiment is shown in Fig. 2.1. The epitaxial layers were grown in a Varian GEN II molecular beam epitaxy system on a piece of twoinch diameter semi-insulating (100) GaAs substrate indium soldered to a molybdenum growth block. The epitaxial layers were grown at a substrate temperature of $600^{\circ} \mathrm{C}$. Si was used as the $\mathrm{n}$-type dopant and $\mathrm{Be}$ as the p-type dopant. The doping densities of the epitaxial layers were determined from the calibrated temperatures of the dopant ovens.

All the diodes were oriented along the (110) planes (the natural cleavage planes.) Alloyed AuGe/Ni/Ti/Au was used for the n-type ohmic contact. The p-type layer was electrically contacted through the substrate via the excess indium left over from the film growth. The n-type contacts were defined by a conventional liftoff technique. Wet etching of the AlGaAs and GaAs layers was performed using 3:3:1:1 $\mathrm{MeOH}: \mathrm{H}_{2} \mathrm{O}: \mathrm{H}_{2} \mathrm{O}_{2}: \mathrm{H}_{3} \mathrm{PO}_{4}$.

After fabrication, the diodes were electrically characterized. Contact was made to the diodes by probing on a micromanipulator model 6000 probe station and electrical data was taken with a Hewlett Packard model 4145 semiconductor parameter analyzer. Following the electrical characterization, the diodes underwent the $\mathrm{As}_{2} \mathrm{~S}_{3}$ chemical treatment.

The $\mathrm{As}_{2} \mathrm{~S}_{3}$ chemical treatment consisted of an oxide removal etch in $1: 10 \mathrm{NH}_{4} \mathrm{OH}: \mathrm{H}_{2} \mathrm{O}$ followed by a 5 minute soak in ammonium sulfide. The sample was then rinsed in deionized water and placed in a solution of $0.16 \mathrm{M} \mathrm{As} s_{2} \mathrm{~S}_{3}$ dissolved in a 1:1 solution of $\mathrm{NH}_{4} \mathrm{OH}: \mathrm{MeOH}$. The sample was then spun dry under flowing nitrogen. Following the $\mathrm{As}_{2} \mathrm{~S}_{3}$ chemical treatment, the diodes were again electrically characterized.

Shown in Fig. 2.2 is the forward current voltage characteristic for a square diode of $50 \mu \mathrm{m}$ on a side before and after the $\mathrm{As}_{2} \mathrm{~S}_{3}$ chemical treatment [13]. At high current levels the device characteristics are dominated by series resistance of the top contact and are not shown. As can readily be seen in Figure 2.2, there is more than an order of magnitude reduction in current after the $\mathrm{As}_{2} \mathrm{~S}_{3}$ chemical treatment at biases above where the shunt leakage dominates. Another significant change due to the $\mathrm{As}_{2} \mathrm{~S}_{3}$ chemical treatment was a reduction in the ideality factor of the diode current from $n=1.7$ to $n=1.5$ for biases where the shunt leakage is negligible, typically greater than $0.5 \mathrm{~V}$. The shunt leakage observed on the treated devices can be eliminated when the sample is annealed in nitrogen at $280^{\circ} \mathrm{C}$. The annealing step is also necessary to make the $\mathrm{As}_{2} \mathrm{~S}_{3}$ film impenetrable to oxygen and permanent. We have not performed this anneal on GaAs pn junctions but have on HBTs which will be discussed in the next section. Similar behavior was observed on all the diodes tested. 


\begin{tabular}{|c|c|c|}
\hline \multicolumn{3}{|c|}{ 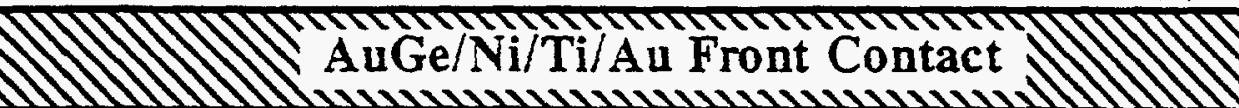 } \\
\hline $\mathbf{n}^{+}$GaAs & $3 \times 10^{18} \mathrm{~cm}^{-3}$ & $1500 \AA$ \\
\hline $\mathrm{n}^{+} \mathrm{Al}_{0.5} \mathrm{Ga}_{0.5} \mathrm{As}$ & $3 \times 10^{18} \mathrm{~cm}^{-3}$ & $500 \AA$ \\
\hline n GaAs & $2 \times 10^{16} \mathrm{~cm}^{-3}$ & $0.5 \mu \mathrm{m}$ \\
\hline $\mathrm{p}^{+}$GaAs & $1 \times 10^{19} \mathrm{~cm}^{-3}$ & $3 \mu \mathrm{m}$ \\
\hline \multicolumn{3}{|c|}{$\mathrm{p}^{+} \mathrm{Al}_{0.5} \mathrm{Ga}_{0.5} \mathrm{As} / \mathrm{GaAs}$ Superlattice } \\
\hline $\begin{array}{c}p^{+} \text {GaAs } \\
\text { Buffer Layer }\end{array}$ & $1 \times 10^{19} \mathrm{~cm}^{-3}$ & $1 \mu \mathrm{m}$ \\
\hline \multicolumn{3}{|c|}{$\mathrm{p}^{+}$GaAs Substrate } \\
\hline & $B$ & \\
\hline
\end{tabular}

Fig. 2.1 Cross-sectional sketch of the GaAs diode. 


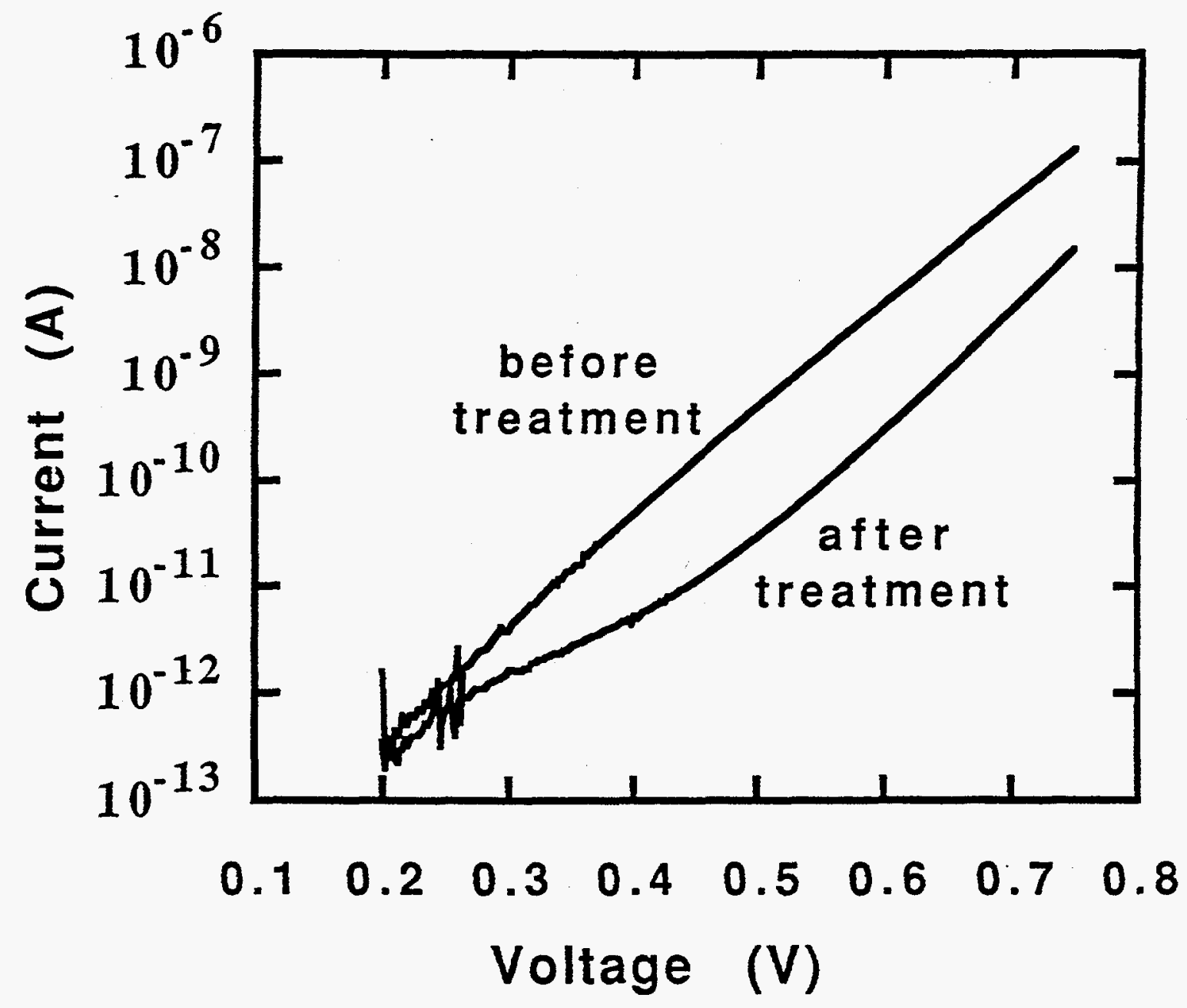

Fig. 2.2 Forward-bias current-voltage characteristic for a square diode of $50 \mu \mathrm{m}$ on a side before and after the $\mathrm{As}_{2} \mathrm{~S}_{3}$ treatment. 


\section{$2.3 \mathrm{As}_{2} \mathrm{~S}_{3}$ PASSIVATION OF HBTs}

The AlGaAs/GaAs HBT structure used in this experiment is shown in Fig. 2.3. The epitaxial layers were grown on a two-inch diameter semi- insulating (100) GaAs substrate at a substrate temperature of $600^{\circ} \mathrm{C}$. The top and bottom of the AlGaAs emitter were parabolically graded to an Al mole fraction of 0.3 over $300 \AA$. All the HBTs were oriented at 45 degree to the (110) planes (the natural cleavage planes) so that wet-etched vertical sidewalls were obtained. Alloyed AuGe/Ni/Ti/Au was used for the n-type contacts to the emitter and collector, and nonalloyed Ti/Au for contact to the p-type base. The emitter contact was used as a mask for both the base etch and the base metallization. A photoresist mask covering the emitter and base contacts was used to define the base and also used as a lift-off mask for the collector metallization. Another photoresist mask was then used to define the collector contact and device isolation. Wet etching of the AlGaAs and GaAs layers were performed using 20:7:1000 $\mathrm{NH}_{4} \mathrm{OH}: \mathrm{H}_{2} \mathrm{O}_{2}: \mathrm{H}_{2} \mathrm{O}$, which provided well-defined vertical sidewalls and an undercut ratio of 1:1. The base and collector contacts were on opposite sides of the emitter as shown in Fig. 2.3.

After fabrication, the HBTs were electrically characterized. Contacts were made to the HBTs by probing on a micromanipulator model 6000 probe station and electrical data was taken with a Hewlett Packard model 4145 semiconductor parameter analyzer. Following the electrical characterization, the HBTs underwent the $A s_{2} \mathrm{~S}_{3}$ chemical treatment. In addition, the $A s_{2} \mathrm{~S}_{3}$ treated HBTs were annealed at $280^{\circ} \mathrm{C}$ on a graphite strip heater in flowing nitrogen for $2 \mathrm{~min}$. This final anneal step makes the $\mathrm{As}_{2} \mathrm{~S}_{3}$ film impermeable to oxygen and results in a permanent passivation.

Following the $\mathrm{As}_{2} \mathrm{~S}_{3}$ chemical treatment, the HBTs were again electrically characterized. Shown in Fig. 2.4 is the collector $\left(\mathrm{I}_{C}\right)$ and base $\mathrm{I}_{\mathrm{B}}$ ) currents as a function of the base-emitter $\left(V_{B E}\right)$ voltage with the base collector junction shorted for an HBT with an emitter size of $14 \mu \mathrm{m}$ $\mathrm{x} 14 \mu \mathrm{m}$ before and after the $\mathrm{As}_{2} \mathrm{~S}_{3}$ chemical treatment. (HBTs with emitter sizes of $14 \mu \mathrm{m} \times 14$ $\mu \mathrm{m}$ were the smallest $\mathrm{HBT}$ s we were able to test after the $A s_{2} \mathrm{~S}_{3}$ treatment without damaging the devices when probing through the $\mathrm{As}_{2} \mathrm{~S}_{3}$ film.) No change was observed in the collector current except for a difference in roll-off at high current levels due to a difference in series resistance. (This difference in series resistance is probably a consequence of the probe contact.) In contrast, there is over an order of magnitude reduction in the base current at biases of $V_{B E}=$ 0.6 to $0.7 \mathrm{~V}$ following the $\mathrm{As}_{2} \mathrm{~S}_{3}$ chemical treatment. Also seen in Fig. 2.4 is that the leakage current initially observed in the base current has been eliminated by the $\mathrm{As}_{2} \mathrm{~S}_{3}$ chemical treatment. Another significant change due to the $\mathrm{As}_{2} \mathrm{~S}_{3}$ chemical treatment was a reduction in the ideality factor of the base current from $n=1.81$ to $n=1.54$ for biases of $V_{B E}=0.7$ to $1.1 V$. (The ideality factor of the collector current for biases of $V_{B E}=0.9$ to $1.2 \mathrm{~V}$ was $n=1.01$ before and 


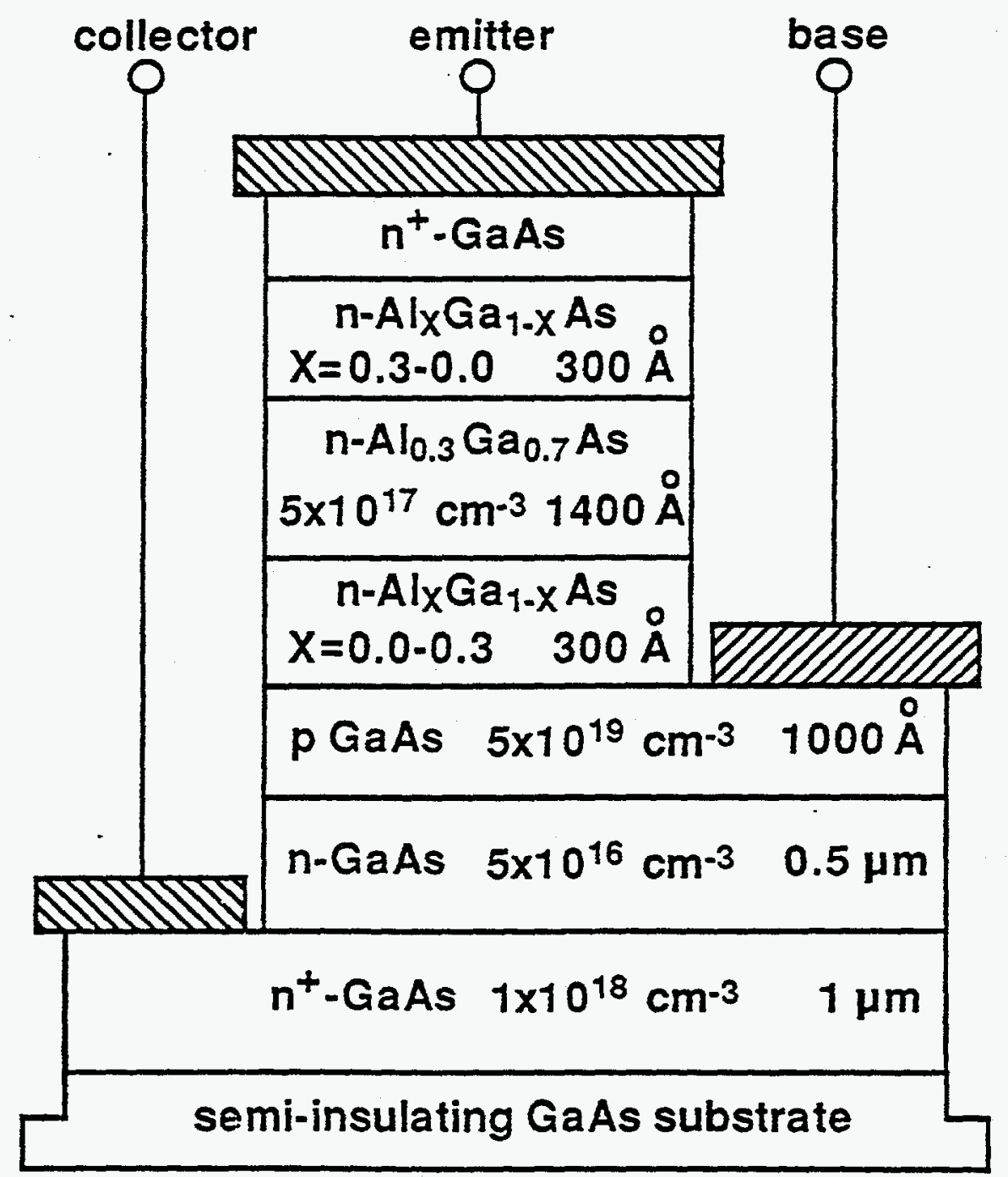

Fig. 2.3 Cross-sectional sketch of the AlGaAs/GaAs heterojunction bipolar transistor. 


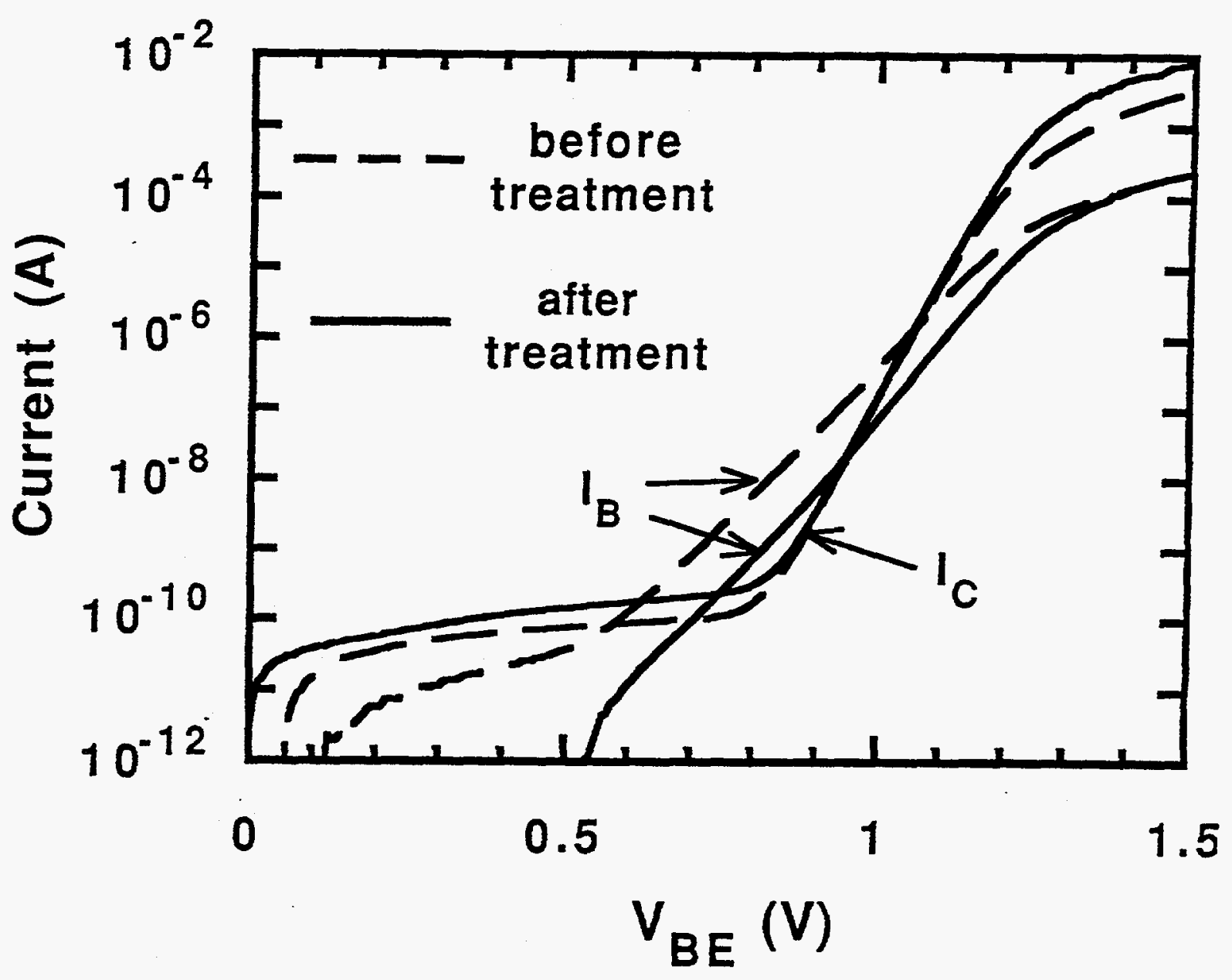

Fig. 2.4 Collector and base currents as a function of base-emitter voltage with the base collector junction shorted. Characteristics before and after the $\mathrm{As}_{2} \mathrm{~S}_{3}$ chemical treatment of the emitter-base perimeter are shown. The emitter size is $14 \mu \mathrm{m} \times 14 \mu \mathrm{m}$. 
after the chemical treatment). Similar behavior was observed with all the treated HBTs and no degradation has been observed after two months exposure to room temperature and atmospheric conditions.

To illustrate the effects of the chemical treatment on the d.c. current gain of the HBT, we have plotted the ratios of the collector to base currents before and after the treatment as a function of the collector current density in Fig. 2.5. Observed in Fig. 2.5 is that the collector current density at which gain is first observed (beta $=1$ ) has been lowered by about two orders of magnitude following the $\mathrm{As}_{2} \mathrm{~S}_{3}$ chemical treatment. Also, the d.c. current gain shows an increase of more than a factor of 10 at the lower current densities. However, the d.c. current gain after the $\mathrm{As}_{2} \mathrm{~S}_{3}$ chemical treatment still exhibits a strong dependence on current density which is caused by a continued presence of a base current component due to recombination in the emitter-base depletion region. There is either still some perimeter recombination or the recombination is dominated by the bulk of the junction in the emitter-base depletion region after the $\mathrm{As}_{2} \mathrm{~S}_{3}$ chemical treatment.

\subsection{SUMMARY}

We have investigated the passivation effects of an $\mathrm{As}_{2} \mathrm{~S}_{3}$ chemical treatment on pn homojunction GaAs diodes and self-aligned HBTs. For a homojunction pn diode of area $50 \mu \mathrm{m} \times 50$ $\mu \mathrm{m}$ more than an order of magnitude reduction was obtained in the dark current due to a reduction in recombination at the mesa-etched perimeter of the diode. The $\mathrm{As}_{2} \mathrm{~S}_{3}$ treatment of the HBT also resulted in over an order of magnitude reduction in the base current at biases of $\mathrm{V}_{\mathrm{BE}}=0.6$ to $0.7 \mathrm{~V}$ while the collector current density at which gain was first observed was lowered by two orders of magnitude. Even after two months exposure to room temperature and atmospheric conditions, no degradation was observed in the HBT characteristics. Further investigations are necessary, but the $A s_{2} S_{3}$ treatment has potential as a permanent passivation of the GaAs surface. 


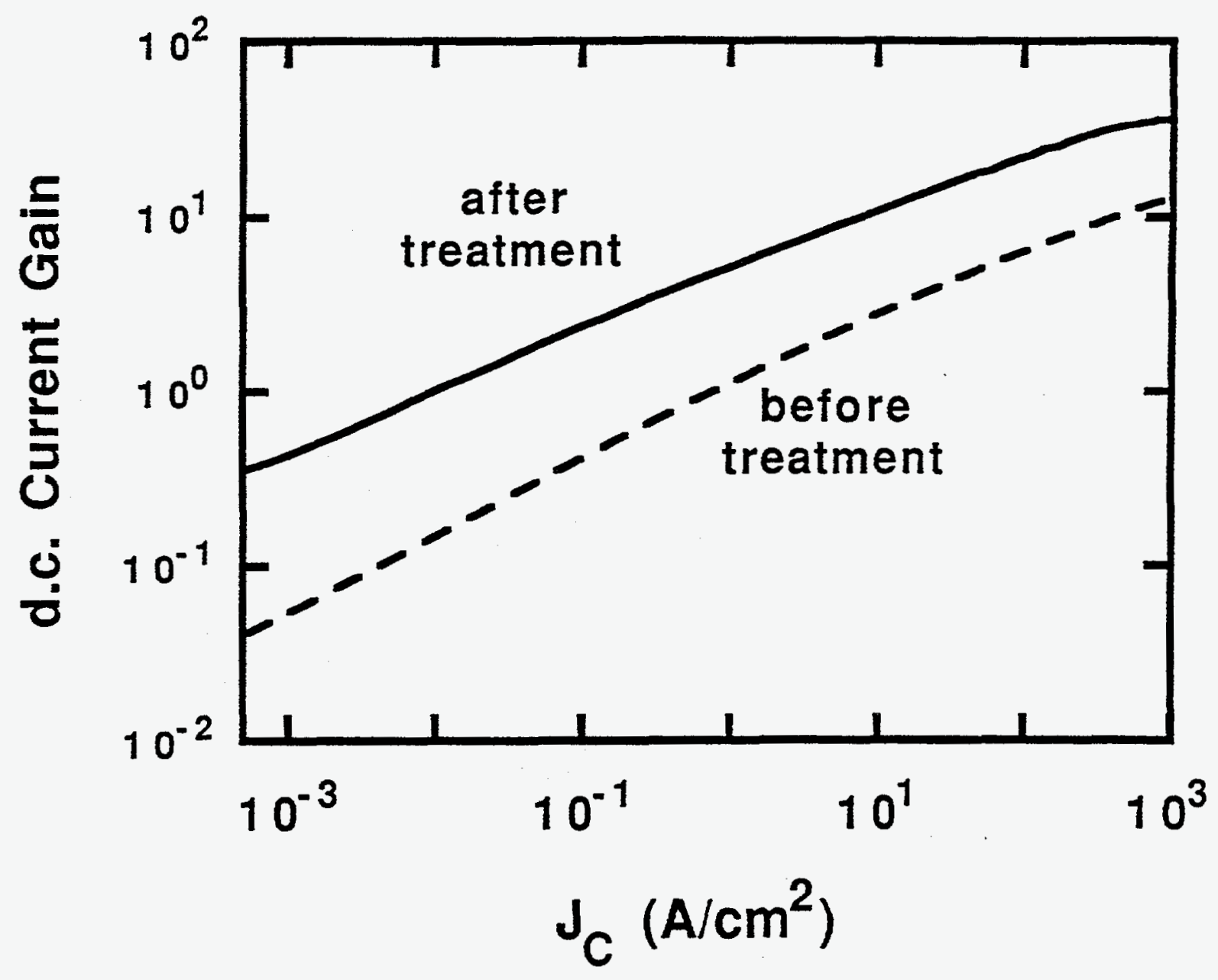

Fig. 2.5 d.c. current gain as a function of collector current density determined from the Fig. 2 HBT characteristics. 


\section{Chapter 2 References}

[1] C. J. Sandroff, R. N. Nottenburg, J. C. Bischoff, and R. Bhat, Appl. Phys. Lett. 51, 33 (1987).

[2] R.N. Nottenburg, C.J. Sandroff, D.A. Humphrey, T.H. Hollenbeck, and R.Bhat, Appl. Phys. Lett. 52, 218(1988).

[3] M.S. Carpenter, M.R. Melloch, M.S. Lundstrom, and S.P. Tobin, Appl. Phys. Lett. 52, 2157(1988).

[4] M.S. Carpenter, M.R. Melloch, and T.E. Dungan, Appl. Phys. Lett. 53, 66(1988).

[5] J.F. Fan, H. Oigawa, and Y. Nannichi, Jpn. J. Appl. Phys. 27, L2125(1988).

[6] E. Yablonovitch, C.J. Sandroff, R. Bhat, and T.J. Gmitter, Appl. Phys. Lett. 51, 439(1987).

[7] E. Yablonovitch, H.M. Cox, and T.J. Gmitter, Appl. Phys. Lett. 52,1002(1988).

[8] C.J. Sandroff, M.S. Hegde, L.A. Farrow, C.C. Chang, and J.P. Harbison, Appl. Phys. Lett. $54,362(1989)$.

[9] B.A. Cowans, Z. Dardas, W.N. Delgass, M.S. Carpenter, and M.R. Melloch, Appl. Phys. Lett. 54, 365(1989).

[10] M.S. Carpenter, M.R. Melloch, B.A. Cowans, Z. Dardas, and W.N. Delgass, J. Vac. Sci. Technol. B7, 845(1989).

[11] E. Yablonovitch, T.J. Gmitter, and B.G. Bagley, submitted to Appl. Phys. Lett.

[12] Paul D. DeMoulin, Stephen P. Tobin, Mark S. Lundstrom, M.S. Carpenter, and Michael R. Melloch, IEEE Elec. Dev. Lett. EDL-9, 368(1988).

[13] T.B. Stellwag, P.E. Dodd, M.S. Carpenter, M.S. Lundstrom, R.F. Pierret, M.R. Melloch, E. Yablonovitch, and T.J. Gmitter, Conference Record of the 21st IEEE Photovoltaic Specialists Conference (IEEE, New York, 1990). 


\title{
CHAPTER 3
}

\author{
LARGE AREA GaAs SOLAR CELLS \\ FABRICATED FROM MBE MATERIAL
}

\subsection{INTRODUCTION}

There has been considerable research and development of high-efficiency GaAs solar cells using material grown by metal-organic chemical vapor deposition (MOCVD) and molecular beam epitaxy (MBE) [1-11]. However, it is only recently that we have demonstrated that GaAs solar cells fabricated from MBE material can have performance comparable to those fabricated from MOCVD material [1,11]. We attribute our improvements in performance of GaAs solar cells fabricated from MBE material to MBE system conditioning, higher purity of source materials, and possibly a reduction in defect density [11]. Solar cells are large area devices and therefore require high material uniformity and low defect densities. The largest previously reported GaAs solar cells fabricated from MBE material have an area of $0.25 \mathrm{~cm}^{2}[1,9,11]$. In this chapter we report on GaAs solar cells of area $2 \times 4 \mathrm{~cm}^{2}$ fabricated from MBE material.

\subsection{DEVICE FABRICATION}

The film used in this work was grown in a Varian GEN II MBE system. The conditioning of the MBE system and sources, and substrate preparation have been reported previously [11]. The cross-section of the cell is shown in Fig. 3.1. The GaAs layers and the $\mathrm{Al}_{0.8} \mathrm{Ga}_{0.2} \mathrm{As}$ window layer were grown at a rate of $1 \mu \mathrm{m}$ per hour and with an $\mathrm{As}_{4}$ to group III beam equivalent pressure of 19. All layers were grown at a substrate temperature of $610^{\circ} \mathrm{C}$. The superlattice below the $\mathrm{n}-\mathrm{GaAs}$ base region consisted of 20 periods of $25 \AA$ of $\mathrm{Al}_{0.36} \mathrm{Ga}_{0.64} \mathrm{As}$ barriers and $25 \AA \mathrm{GaAs}$ wells. The purpose of the superlattice was to act as a back surface field to confine minority carrier holes to the $n-G a A s$ base region to enhance their collection by the pn junction. Two $\mathrm{Ga}$ effusion furnaces were used with each producing a growth rate of $0.5 \mu \mathrm{m}$ per hour for most of the growth. Towards the end of the growth of the p-GaAs emitter region, the temperatures of the gallium ovens were adjusted so that the $\mathrm{Al}_{0.8} \mathrm{Ga}_{0.2} \mathrm{As}$ window layer could be grown by closing the shutter of one of the $\mathrm{Ga}$ furnaces while opening the shutter to the $\mathrm{Al}$ furnace. A 5 


\begin{tabular}{|c|c|c|}
\hline AR Coating & Grid & \\
\hline $\mathrm{PAl}_{0.8} \mathrm{Ga}_{0.2^{\mathrm{As}}}$ & Metallization & $500 \AA$ \\
\hline$p$ GaAs & $2 \times 10^{18} \mathrm{~cm}^{-3}$ & $0.4 \mu \mathrm{m}$ \\
\hline n GaAs & $2 \times 10^{17} \mathrm{~cm}^{-3}$ & $3 \mu \mathrm{m}$ \\
\hline $\begin{array}{l}20 \text { period superlat } \\
25 \AA \mathrm{Al}_{0.36} \mathrm{Ga}_{0.6}\end{array}$ & As /25 A GaAs & \\
\hline $\begin{array}{l}\mathrm{n}^{+} \text {GaAs } \\
\text { Buffer Layer }\end{array}$ & $1 \times 10^{18} \mathrm{~cm}^{-3}$ & $1 \mu \mathrm{m}$ \\
\hline & GaAs Substrate & \\
\hline
\end{tabular}

Fig. 3.1 Cross-section of the GaAs solar cell. 
second growth interruption was incorporated between the $\mathrm{p}-\mathrm{GaAs}$ emitter and $\mathrm{Al}_{0.8} \mathrm{Ga}_{0.2} \mathrm{As}$ window regions to produce a smoother hetero-interface. After film growth, a $2 \times 4 \mathrm{~cm}^{2}$ solar cell was fabricated from the $5.08 \mathrm{~cm}$ diameter wafer at the Applied Solar Energy Corporation. The front grid metalization covered $7 \%$ of the area of the cell and made contact directly to the $p$ GaAs emitter region. A double layer antireflection (AR) coating was used.

\subsection{EXPERIMENTAL RESULTS}

The cell was measured under 1-sun AM1.5 conditions at the Solar Energy Research Institute by Keith Emery and exhibited an efficiency of $21.7 \%$ at a temperature of $25^{\circ} \mathrm{C}$. Displayed in Fig. $3.2 \mathrm{a}$ is the cell's current voltage characteristic along with the measured solar cell parameters under 1-sun AM1.5 conditions. The cell was also measured under 1-sun AM0 conditions at Applied Solar Energy Corporation and exhibited an efficiency of $18.8 \%$ at a temperature of $28^{\circ} \mathrm{C}$. Displayed in Fig. $3.2 \mathrm{~b}$ is the cell's current voltage characteristic along with the measured solar cell parameters under 1-sun AMO conditions. These results are comparable to those obtained for $2 \times 4 \mathrm{~cm}^{2}$ cells which have been grown by MOCVD [5]. Displayed in Fig. 3.3 is the internal quantum efficiency(IQE) for our cell. A high collection efficiency is seen in the Fig. 3.3 IQE data for short wavelengths indicating a high quality $\mathrm{Al}_{0.8} \mathrm{Ga}_{0.2} \mathrm{As}$ window layer/pGaAs emitter layer hetero-interface. The high collection efficiencies observed for the IQE at long wavelengths indicates a good minority carrier hole diffusion length in the $\mathrm{n}-\mathrm{GaAs}$ base region of the cell.

MBE material is plagued by a defect which has become known as the "oval" defect due to its shape. Two sources of oval defects have been identified, particulate contamination and excess gallium accumulation during growth [12]. Our films routinely exhibit oval defect densities in the range of $500-1000 \mathrm{~cm}^{-2}$. We therefore have on the order of $4000-8000$ oval defects in our $2 \times 4 \mathrm{~cm}^{2}$ solar cell! We have previously found that these oval defects result in leakage currents in our solar cells which degrade the fill factor and hence the efficiencies [11]. Plotted in Fig. 3.4 is the log of current versus voltage for the $2 \times 4 \mathrm{~cm}^{2}$ solar cell along with a dashed line displaying a voltage dependence $\mathrm{e}^{\mathrm{qV} / 2 \mathrm{kT}}$. Clearly seen in Fig. 3.4 is that the $2 \times 4 \mathrm{~cm}^{2}$ solar cell exhibits leakage currents which result in diode ideality factors which are greater than 2 . In spite of the leakage currents the $2 \times 4 \mathrm{~cm}^{2}$ solar cell demonstrated state-of-the-art performance. 


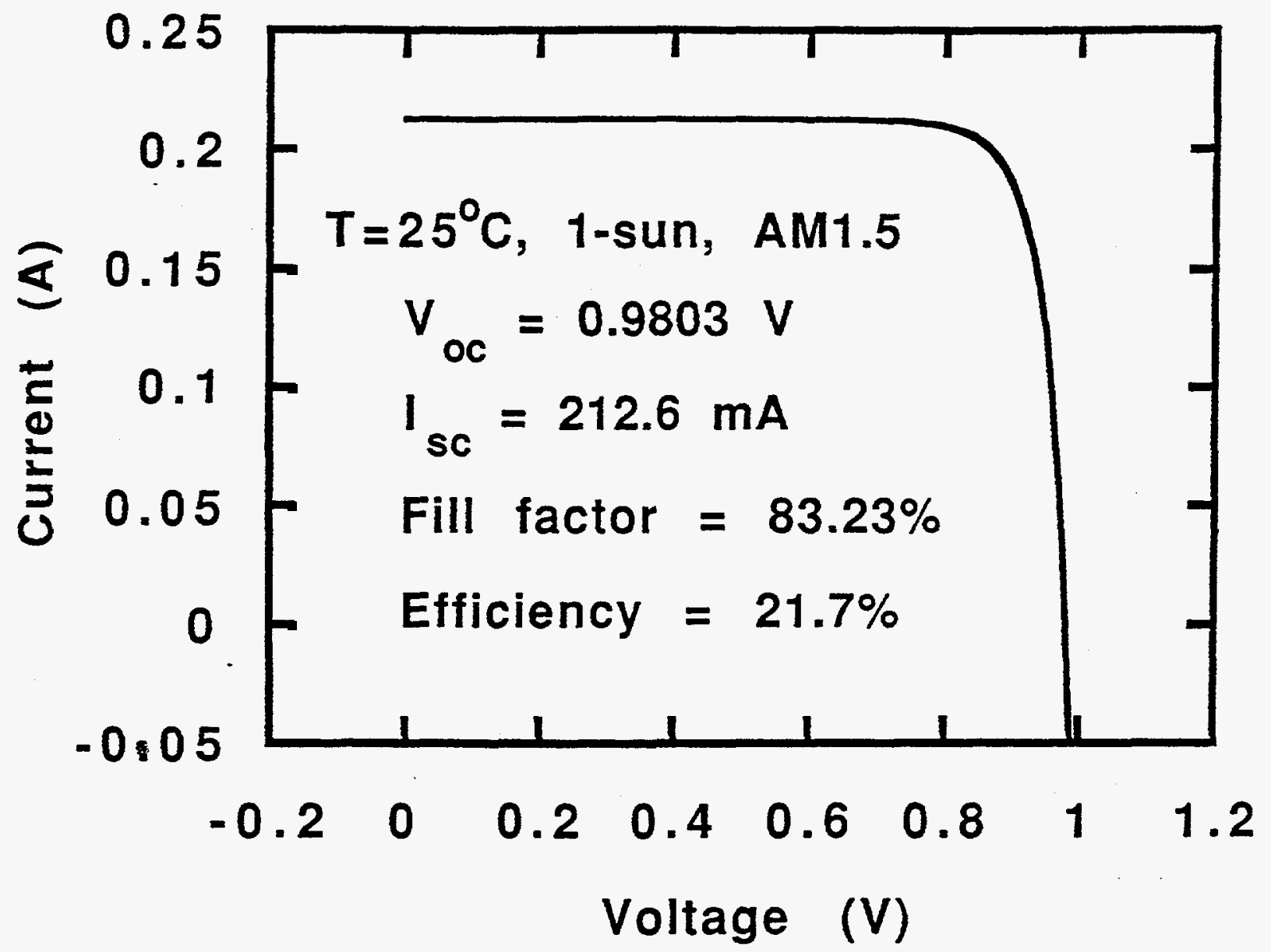

Fig. 3.2a Current-voltage characteristics and measured solar cell parameters of the $2 \times 4 \mathrm{~cm}^{2}$ solar cell under 1-sun AM1.5 conditions. 


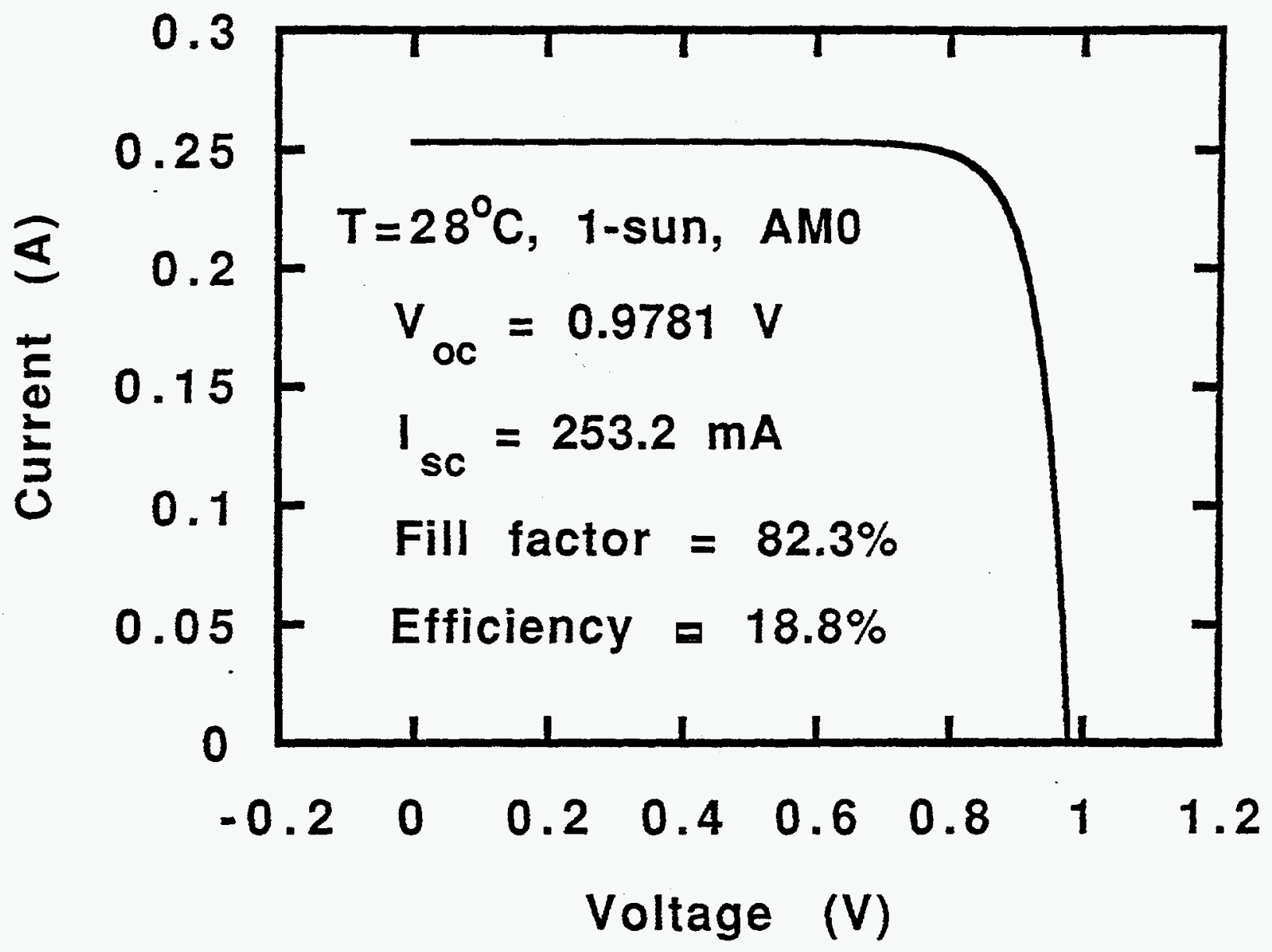

Fig. 3.2b Current-voltage characteristics and measured solar cell parameters of the $2 \times 4 \mathrm{~cm}^{2}$ solar cell under 1-sun AM0 conditions. 


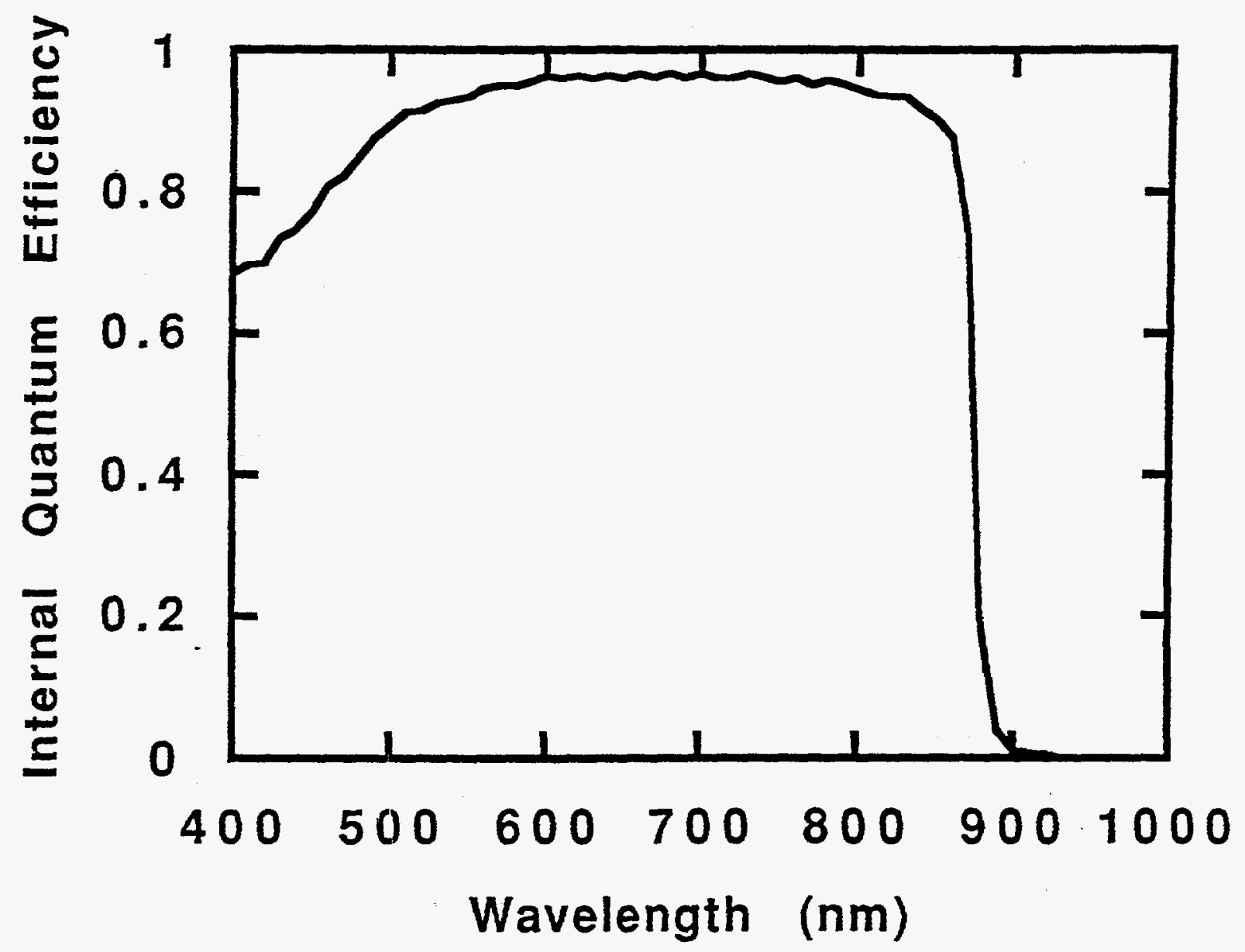

Fig. 3.3 Internal quantum efficiency of the $2 \times 4 \mathrm{~cm}^{2}$ solar cell. 


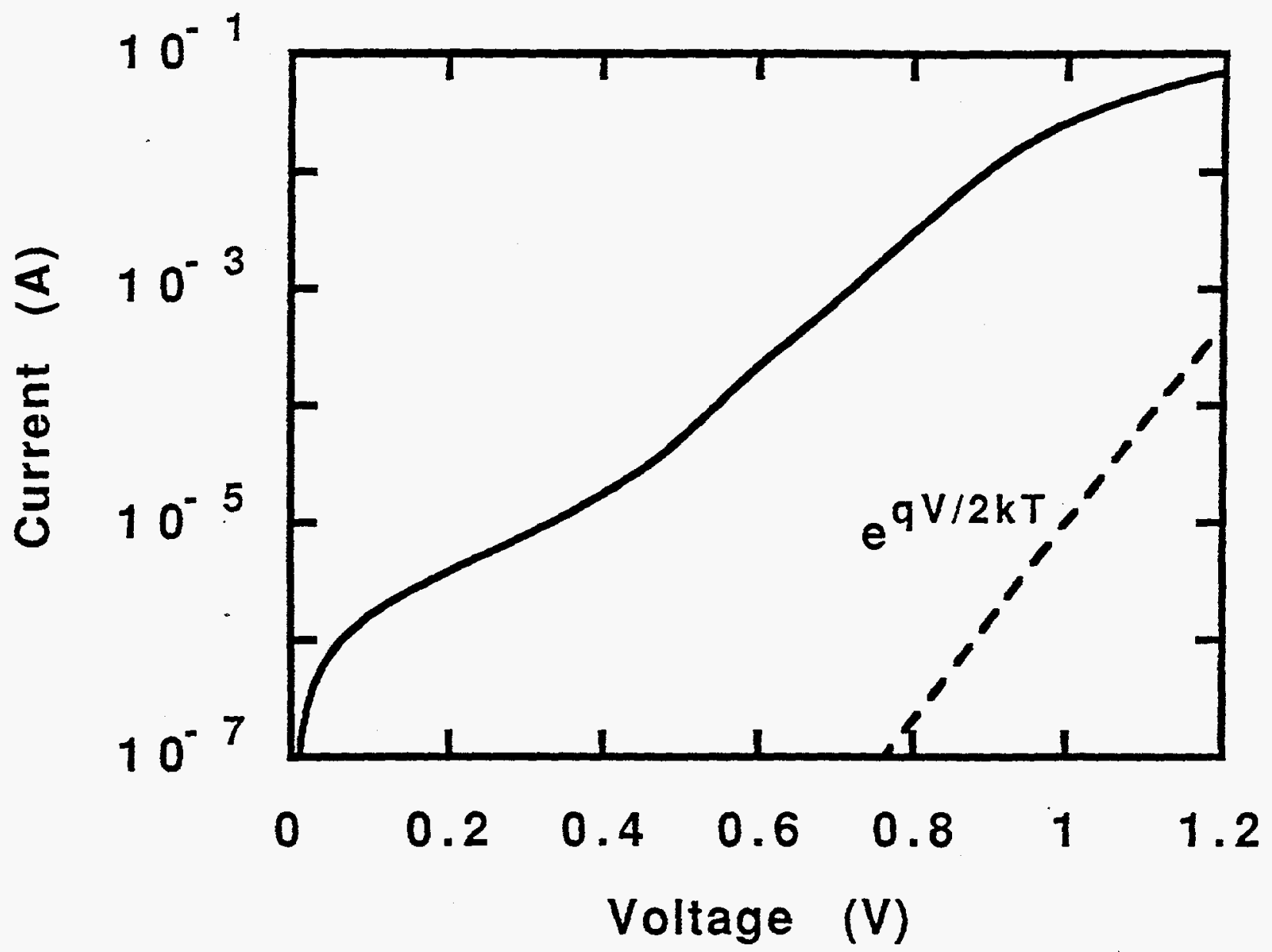

Fig. 3.4 Dark current-voltage characteristics of the $2 \times 4 \mathrm{~cm}^{2}$ solar cell. 


\subsection{SUMMARY}

We have fabricated $2 \times 4 \mathrm{~cm}^{2} \mathrm{GaAs}$ solar cells from MBE material. This is the largest device ever fabricated from an MBE film. The cell demonstrated an efficiency of $18.8 \%$ under 1sun $A M 0$ conditions which is comparable to results obtained for similar size cells fabricated from MOCVD material.

\section{ACKNOWLEDGEMENT}

The processing of the $2 \times 4 \mathrm{~cm}^{2}$ solar cell was perfomed at Applied Solar Energy Corporation thanks to Peter Mes, Frank Ho, and Charles Chu. Some of the solar cell efficiency measurements reported in this chapter were performed by Keith Emery of SERI. 


\section{Chapter 3 References}

[1] S.P. Tobin, S.M. Vernon, C. Bajgar, S.J. Wojtczuk, M.R. Melloch, A. Keshavarzi, T.B. Stellwag, S. Venkatesan, M.S. Lundstrom, and K.A. Emery, "Assessment of MOCVD- and MBE-Grown GaAs for High-Efficiency Solar Cell Applications," IEEE Trans. Electron Devices, vol.37, no. 2, p.469, 1990.

[2] R.P. Gale, R.W. McClelland, B.D. King, and J.W. Gormley, "High-Efficiency Thin-Film AlGaAs-GaAs Double Heterostructure Solar Cells," Conference Record of the 20th IEEE Photovoltaic Specialists Conference, p. 446-450, Las Vegas, Nevada, Sept. 26-30, 1988.

[3] S.P. Tobin, and S.M. Vernon, "High Efficiency GaAs and GaAs/Ge Tandem Solar Cells," Technical Digest of the 4th International Photovoltaic Science and Engineering Conference, Sydney, Australia, February 14-17, 1989.

[4] K. Bertness, M. Ladle Ristow, and H.C. Hamaker, "High-Efficiency GaAs Solar Cells From a Multiwafer OMVPE Reactor," Conference Record of the 20th IEEE Photovoltaic Specialists Conference, p.769, Las Vegas, Nevada, Sept. 26-30, 1988.

[5] P.A. Iles, Yea-Chuan M. Yeh, F.H. Ho, Chaw-Long Chu, and C. Cheng, "High-Efficiency (>20\%AM0) GaAs Solar Cells Grown on Inactive-Ge Substrates," IEEE Elec. Dev. Lett. , vol. 11, no. 4, p.140, 1990.

[6] J.M. Olson, Sarah R. Kurtz, and A. Kibbler, "High Efficiency GaAs Solar Cells Using GaInP ${ }_{2}$ Window Layers," 21st IEEE Photovoltaic Specialist Conference, Kissimmee, Florida, May 22-25, 1990.

[7] A. Saletes, J.P. Contour, M. Leroux, J. Massies, N. Defranould, and G. Pelous, "GaAlAs/GaAs Solar Cells Grown by Molecular Beam Epitaxy: Material Properties and Device Parameters," Solar Cells, vol. 17, p. 373, 1986.

[8] John C.C. Fan, A.R. Calawa, Ralph L. Chapman, and George Turner, "Efficient ShallowHomojunction GaAs Solar Cells by Molecular Beam Epitaxy," Appl. Phys. Lett., vol. 35, no. 10, p. 804, 1979.

[9] D.L. Miller and J.S. Harris, Jr., "Molecular Beam Epitaxial GaAs Heteroface Solar Cell Grown on Ge," Appl. Phys. Lett., vol. 37, no. 12, p.1104, 1980.

[10] Chikara Amano, Masafumi Yamaguchi, and Atsushi Shibukawa, "Optimization of Radiation-Resistant GaAs Solar Cell Structures," Technical Digest of the First International Photovoltaic Science and Engineering Conference, Kobe, Japan, p. 845, 1984.

[11] M.R. Melloch, S.P. Tobin, T.B. Stellwag, C. Bajgar, A. Keshavarzi, M.S. Lundstrom, and K. Emery, "High-efficiency GaAs Solar Cells Grown by Molecular-Beam Epitaxy," J. 
Vac. Sci. Technol. B, vol 8, no. 2, p. 379, 1990.

[12] S. Matteson and H.D. Shih, "Morphological Studies of Oval Defects in GaAs Epitaxial Layers Grown by Molecular Beam Epitaxy," Appl. Phys. Lett, vol. 48, no. 1, p. 57, 1986. 


\section{CHAPTER 4}

\section{THE THIN-FILM APPROACH to HIGH EFFICIENCY}

\subsection{INTRODUCTION}

The reported efficiencies of both silicon and GaAs solar cells under concentration are now approaching the $30 \%$ barrier. Single junction $\mathrm{GaAs}$ cells have achieved a one-sun efficiency of $25.7 \%^{1}$ and a concentrator efficiency of $29.2 \%{ }^{2}$. GaAs is also employed as part of a tandem stack with such diverse semiconductors as germanium, $\mathrm{GaSb}, \mathrm{Al}_{\mathrm{x}} \mathrm{Ga}_{1-\mathrm{x}} \mathrm{As}, \mathrm{GaInP} \mathrm{P}_{2}$, and silicon with efficiencies reaching as high as $35 \% \%^{3-8}$. GaAs cells have become the workhorse of highefficiency solar cell technology and research. Though these results are promising, single junction GaAs cells are approaching limits of efficiency established by computer simulation ${ }^{9}$ and imposed by the fundamental limit of radiative recombination and their design. These efficiencies are far below calculated theoretical limits of $31 \%$ and $37 \%$ for one-sun and concentrator cells respectively, assuming the radiative recombination limit ${ }^{10}$. To achieve significantly higher efficiencies in single junction cells, new designs are necessary.

Thin film cells have been studied before as a way to circumvent the high cost of GaAs substrates $^{11}$. In this chapter we argue that thin-film designs, where the solar cell is removed from the substrate, offer the potential for single junction GaAs cells with conversion efficiencies over $35 \%$. These new designs employ light-trapping techniques which have contributed significantly to silicon concentrator solar cell efficiencies approaching the $30 \%$ level. We begin by analyzing the losses and limitations of present day GaAs cells and showing that even with significant improvements, today's designs cannot produce a $35 \%$ efficient, single junction GaAs solar cell. We then show that only by decreasing the active volume of the cell while maintaining the optical thickness can a further increase in efficiency be achieved. Light-trapping is used to maintain the optical thickness while decreasing the actual thickness. In thin film GaAs cells, implementing light-trapping of incident sunlight requires separation of the active volume from the substrate which results in a bonus of enhanced photon recycling ${ }^{12-14}$. Photon recycling is the reabsorption of photons emitted during a radiative recombination event, which creates a new electron-hole pair, thereby increasing the effective lifetime of carriers in GaAs. A design is presented and efficiency projections are done which demonstrate that efficiencies above $35 \%$ 
are possible.

\subsection{BACKGROUND}

To assess the factors which limit the efficiency of the best present day cells, a recently published, $24.8 \%$ efficient, one-sun AM1.5 GaAs solar cell is analyzed ${ }^{15}$. The structure of this cell is typical of most present day high-efficiency cell designs, and is shown in Fig. 4.1, and its measured output parameters are listed Table 4.1.

\begin{tabular}{|c|c|c|}
\hline Parameter & $\begin{array}{c}\text { Measured } \\
\text { Value }\end{array}$ & $\begin{array}{c}\text { Modeled } \\
\text { Value }\end{array}$ \\
\hline \hline $\mathrm{V}_{\propto c}$ (volts) & 1.029 & 1.040 \\
$\mathrm{~J}_{\mathrm{sc}}(\mathrm{mA})$ & 27.89 & 27.9 \\
Fill Factor & 0.864 & 0.862 \\
Efficiency (\%) & 24.8 & 24.9 \\
\hline
\end{tabular}

Table 4.1 Comparison of measured and modeled solar cell parameters for the cell sketched in Fig. 4.1

Loss analysis is performed at the $J_{s c}$ and $V_{\propto c}$ biases. $J_{s c}$ losses can be found from measurements of the internal quantum efficiency (IQE) of the solar cell while $V_{\propto}$ losses can be found by combining the IQE with the dark current. The percent losses in each region of the cell at these biases are shown in the pie charts of Figs. 2. One can see that the losses at $J_{s c}$ are concentrated outside the active cell in the form of reflection and shadowing losses. Significant losses are also attributed to absorption in the window and to photons left unabsorbed by the active volume. Losses at $\mathrm{V}_{\infty}$ are dominated by diffusion current injected into the emitter which is adversely affected by bandgap narrowing ${ }^{16}$. The reported cell output parameters can be used as a test of this efficiency projection procedure. The $J_{s c}$ is computed by weighting the external 


\begin{tabular}{|c|c|c|}
\hline \multirow{2}{*}{$\frac{\mathrm{Cr} / \mathrm{Au}}{\mathrm{p}^{+} \mathrm{GaAs}}$} & \multirow{2}{*}{\multicolumn{2}{|c|}{ AR Coating }} \\
\hline & & \\
\hline \multicolumn{2}{|c|}{$\mathrm{p} \mathrm{Al} \mathrm{Al}_{0.8} \mathrm{Ga}_{0.2} \mathrm{As}$} & $0.03 \mu \mathrm{m}$ \\
\hline $\mathrm{p}$ GaAs & $4 \times 10^{18} \mathrm{~cm}^{-3}$ & $0.66 \mu \mathrm{m}$ \\
\hline n GaAs & $2 \times 10^{17} \mathrm{~cm}^{-3}$ & $3-4 \mu \mathrm{m}$ \\
\hline \multicolumn{2}{|c|}{$\mathrm{n}^{+} \mathrm{Al}_{0.3} \mathrm{Ga}_{0.7} \mathrm{As}$} & $1.0 \mu \mathrm{m}$ \\
\hline $\mathrm{n}^{+} \mathrm{GaAs}$ & $1 \times 10^{18} \mathrm{~cm}^{-}$ & \\
\hline \multicolumn{3}{|c|}{$\mathrm{n}^{+} \mathrm{GaAs}$ Substrate } \\
\hline $\mathrm{Au}: \mathrm{Ge} / \mathrm{A}$ & Back Contact & \\
\hline
\end{tabular}

Fig. 4.1 Representative cell structure for a P on N GaAs heteroface solar cell. 

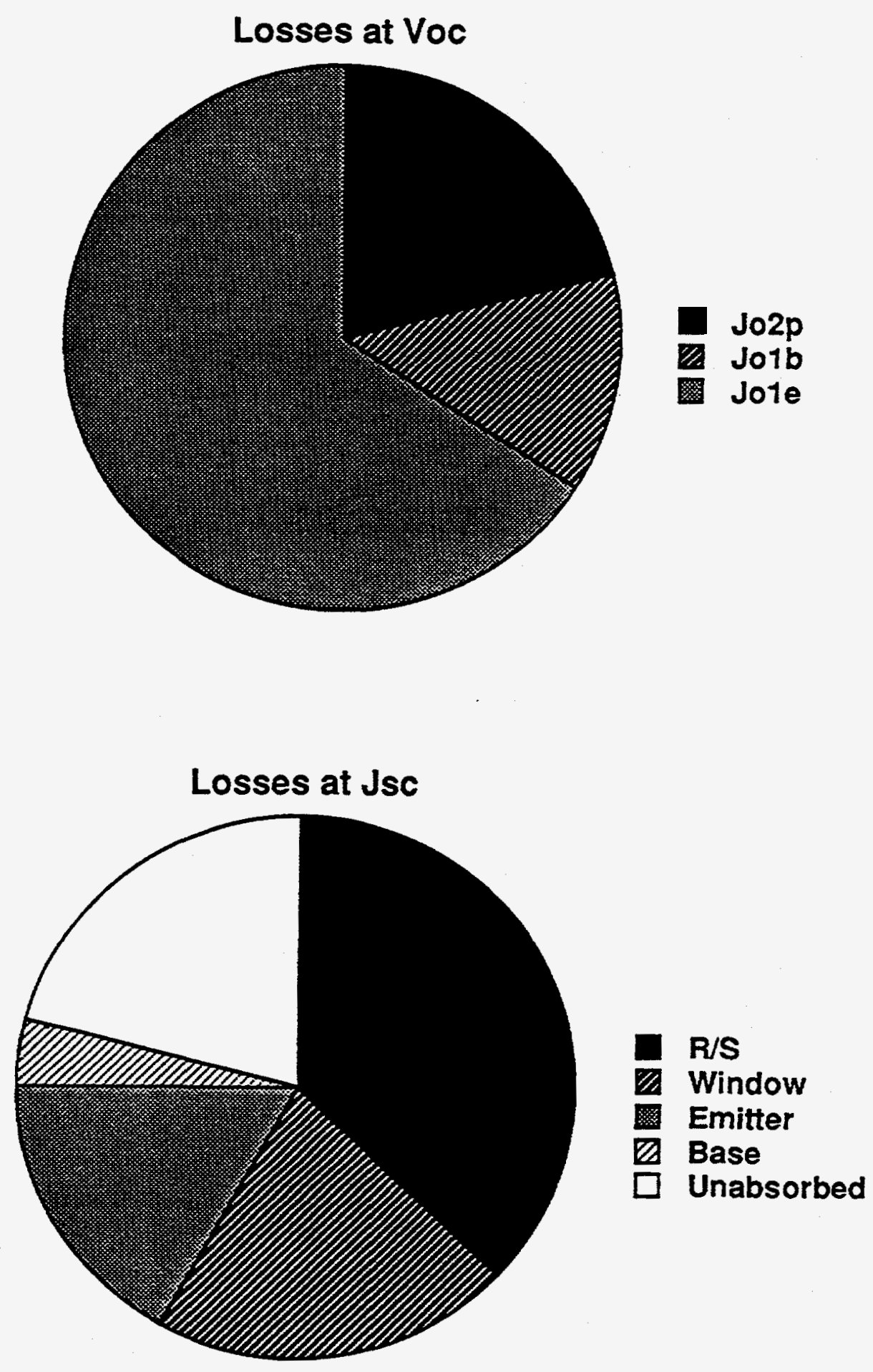

Fig. 4.2 Computed losses for the cell sketched in Fig. 4.1. 
quantum efficiency with the AM1.5 spectrum. The diffusion saturation current density is computed from the parameters deduced from a fit to the IQE data using the IQE model of Hovel and Woodall ${ }^{17}$. The space charge recombination saturation current density is found from measurements of the dark current-voltage characteristic. These are then used to compute a currentvoltage relationship for the solar cell under illumination which yields the cell parameters. The parameters computed by this method, listed in Table 4.1, match well the reported values, giving credibility to our model.

The potential efficiency of this cell can then be easily be projected to the radiative limit. We use the radiative lifetimes of Casey and Panish ${ }^{18}$ and Hwang ${ }^{19}$ for p- and n-type GaAs respectively, and values reported for the interface recombination velocities for this cell ${ }^{20,21}$. These are used to compute the radiative limit light current and dark current, including bandgap narrowing in the p-type emitter. The projected efficiency of this cell is $25.2 \%$ which is only 0.4 percentage points above the measured efficiency. We conclude that present day GaAs solar cells are nearing the radiative limit.

It is also of interest to see how good this cell can be with the major $J_{s c}$ losses suppressed. The lack of losses in the base suggests that a thicker base could be used to reduce the losses due to unabsorbed photons. Also, losses due to shadowing can be reduced through prismatic coverslides. By suppressing these loss mechanisms, the $\mathrm{J}_{\mathrm{sc}}$ becomes 30.4 milliamps. In the radiative limit this projects to a cell efficiency of $27.2 \%$. Under 500 suns concentration and ignoring series resistance, this correlates to an efficiency of $32.8 \%$ which is quite close to a numerical projection made by Demoulin and Lundstrom ${ }^{9}$. Thus, significant improvement in the performance of this design cannot produce a $35 \%$ efficient cell, even in the radiative limit. Once the two main loss mechanisms of the $J_{s c}$ are suppressed, this cell design will have been taken essentially to its limit of efficiency. To obtain a significant increase in efficiency for GaAs solar cells, new device designs are necessary.

\subsection{LIGHT TRAPPING in THIN GaAs SOLAR CELLS}

Suppression of the dark current, which manifests itself in the $V_{o c}$, is one way to improve cell efficiencies. The losses at $V_{o c}$ are dominated by diffusion current which accounts for $81 \%$ of the total dark current at this bias. The remaining dark current loss is due to space charge recombination which is dominated by recombination at the perimeter of the cell mesa. Since the bulk lifetimes are near the radiative limit, the only way to suppress recombination further is to reduce the volume available for diffusion current recombination. But this cannot be done at the expense of reducing the optical thickness of the cell or the $\mathrm{J}_{\mathrm{sc}}$ will suffer. New designs must 
couple a reduction of the magnitude of the dark current while maintaining or improving the present collection efficiency at $J_{\text {se }}$.

Figure 4.3 shows a GaAs cell designed to employ light-trapping. The cell is $\mathrm{N}$ on $\mathrm{P}$ rather than $P$ on $N$ so that a thinner emitter can be employed without incurring sheet resistance problems. Light-trapping is provided by a prismatic coverglass and a reflecting back contact. A similar scheme has been used for a bifacial silicon solar cell which was the first bifacial silicon cell to exceed $25 \%$ efficiency under concentration ${ }^{22}$. Fabrication of such a cell in GaAs, however, requires the ability to separate the active volume from the GaAs substrate. One approach is the cleft process ${ }^{11}$. Another technique uses an etch highly selective to high $\mathrm{Al}$ mole fraction $\mathrm{AlGaAs}^{23}$. After contacting the emitter and applying the anti-reflection coating, the thin film would be lifted off from the substrate using Yablanovitch's liftoff technique. The thin film is then supported mechanically by a masking black wax. Next, the back side is metallized and the black wax removed. The thin film cell is then Van der Waals bonded or attached with a conductive adhesive to a metallized substrate before the coverglass is attached. This process of separating the solar cell from its substrate to facilitate light-trapping is certainly labor-intensive though high yield has been demonstrated for the the liftoff procedure ${ }^{23}$. The lift-off approach is well-suited to research applications but may not be the best process for manufacturing cells.

This task of separating the solar cell from the substrate creates a second benefit by enhancing photon recycling. The degree of effective lifetime enhancement due to photon recycling is determined by the likelihood that an emitted photon is reabsorbed before exiting the active volume. As the recombination internal quantum efficiency, defined as the ratio of radiative recombination events to the total number of recombination events, nears unity and the photon is likely to be reabsorbed, then photon recycling can significantly increase the observed lifetime of a semiconductor. Photon recycling has been observed in double heterostructures and in solar cells with the substrate still intact ${ }^{20,21,24}$.

By removing the substrate, which is a sink for luminescence photons, we significantly increased the probability that the emitted photons remain confined to the active volume so they are more likely to be reabsorbed thus enhancing photon recycling. Fig. 4.4 depicts the enhanced photon confinement in a thin film cell after substrate removal. Transient luminescence studies of double heterostructures have also shown that removing the substrate results in an observed lifetime enhancement of up to 15 times $^{25}$.

The techniques of the previous section can be used to project the efficiency of the cell shown in Fig. 4.3. We assume that light-trapping allows this new design to maintain the $J_{s c}$ of $30.4 \mathrm{~mA}$ projected to be attainable in the improved present day cell discussed above. Once again we use the radiative lifetimes of Casey and Panish ${ }^{18}$ and Hwang ${ }^{19}$ for $p$ - and n-type GaAs 


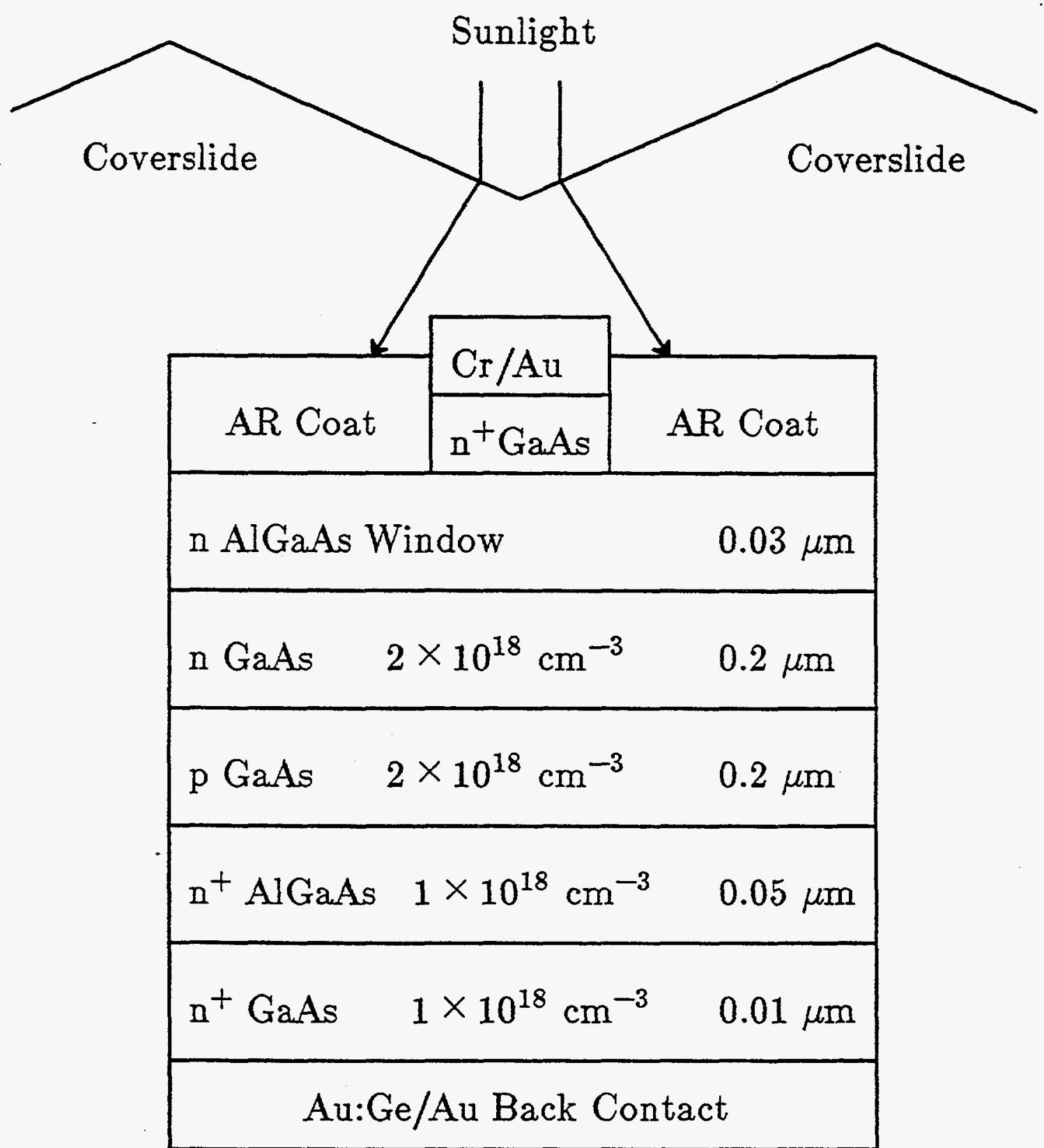

Fig. 4.3 Proposed design for a thin-film GaAs cell. 


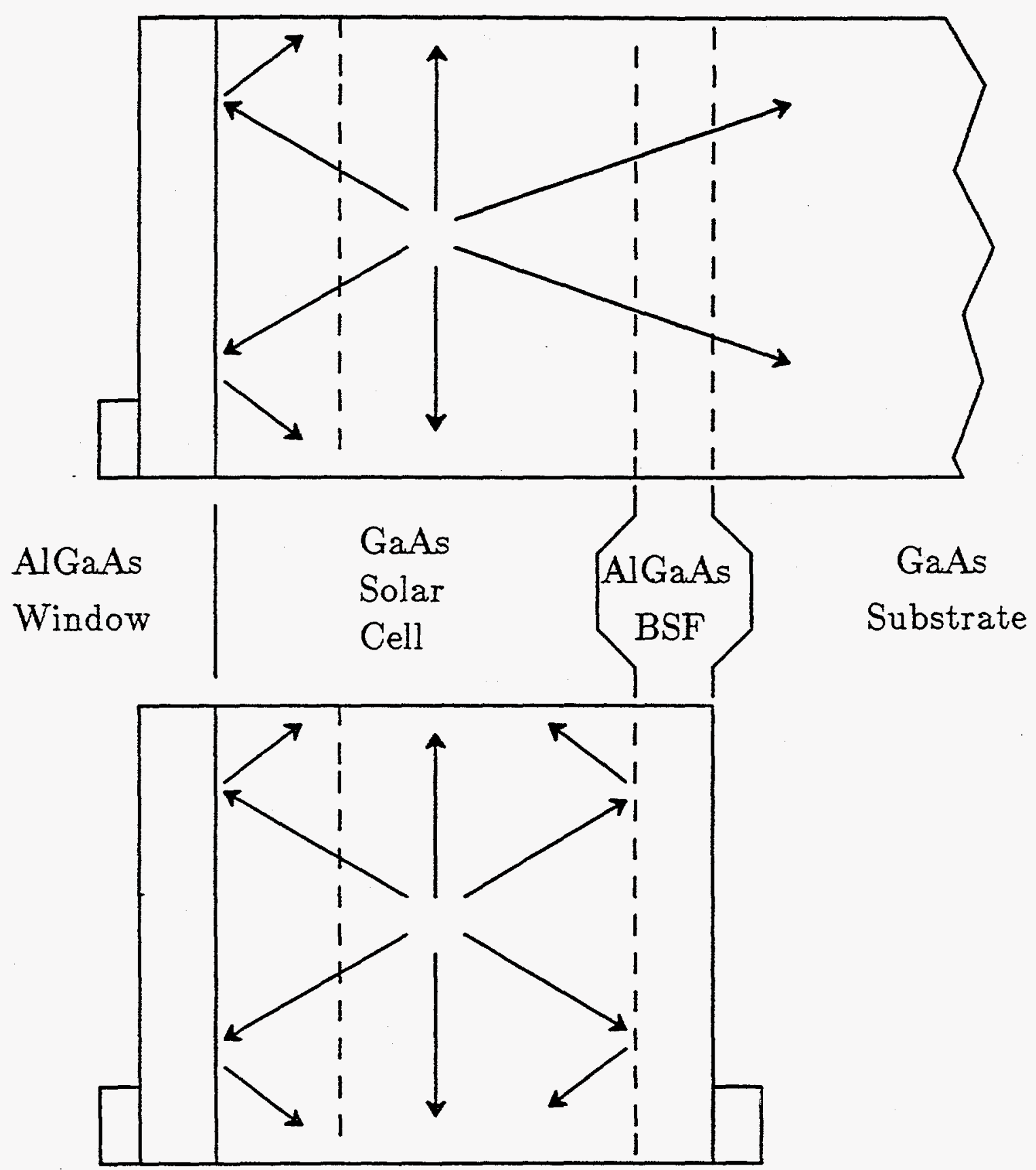

Fig. 4.4 Illustration of how photons emitted as a result of radiative recombination are confined and reabsorbed in a thin cell. 
respectively, and the same values for the interface recombination velocities used above ${ }^{21}$. We include bandgap narrowing, this time in the p-type base. At the radiative limit, the efficiency of this cell is projected to be $27.9 \%$ at one-sun AM1.5 and $34.9 \%$ under 500 suns concentration, a two point increase over the thicker cell which was projected to $32.8 \%$ above. Accounting for the expected bifetime enhancement from improved photon recycling, these efficiencies are projected to $28.0 \%$ and $35.3 \%$. The small improvement shows that the diffusion current is now dominated by recombination at the front and back GaAs/AlGaAs interfaces.

\subsection{ISSUES and CONCLUSIONS}

The most prohibitive issue in the development of this new design will be the handling and processing of fragile, thin films. The processing steps will be labor intensive so cost will be an issue. Thermal stress may also be important under concentration since the thin film cell after liftoff will be mounted on a substrate other than GaAs.

Modeling these cells will also be quite challenging. Light-trapping will have to be simulated possibly using recently developed ray tracing programs to describe the propagation of sunlight normally incident on a textured cell. More challenging will be properly accounting for photon recycling.

To conclude, a loss analysis for the conventional heteroface cell design demonstrates that present-day cells are approach radiative recombination limited efficiency. A new design approach based on the use of ultra-thin GaAs to achieve light trapping promises significant performance advantages with the same material quality. Thin-film GaAs cells can benefit from light trapping in the same way that silicon cells do. For GaAs cells, however, the thin-films approach can also lead to longer effective bulk lifetimes by enhancing photon recycling. We conclude that the thin-film approach is a promising avenue for high-efficiency, III-V cell research. 


\section{Chapter 4 References}

1. S. R. Kurtz, “25.7\% Record," Solar Cells, 1990.

2. N. R. Kaminar, D. D. Liu, H. F. Macmillan, L. D. Partain, M. Ladle Ristow, and G. F. Virshup, "Concentrator Efficiencies of $29.2 \%$ for a GaAs Cell and $24.8 \%$ for a Mounted Cell-Lens Assembly," Conf. Rec., 20th IEEE Photovoltaic Specialists Conf., p. 766, IEEE, New York, 1988.

3. J. Gee and G. F. Virshup, "A 31\%-Efficient GaAs/Silicon Mechanically Stacked, Multijunction Concentrator Solar Cell," Conf. Rec., 20th IEEE Photovoltaic Specialists Conf., p. 754, IEEE, New York, 1988.

4. S. T. Tobin, S. M. Vernon, C. Bajgar, V. E. Haven, L. M. Geoffrey, M. M. Sanfacon, D. R. Lillington, R. E. Hart, K. A. Emery, and R. J. Matson, "High Efficiency GaAs/Ge Monolithic Tandem Solar Cells," Conf. Rec., 20th IEEE Photovoltaic Specialists Conf., p. 405, IEEE, New York, 1988.

5. B.-C. Chung, G. F. Virshup, S. Hikido, and N. R. Kaminar, "27.6\% Efficiency (1 sun, Air Mass 1.5) Monolithic $\mathrm{Al}_{0.37} \mathrm{Ga}_{0.63} \mathrm{As} / \mathrm{GaAs}$ Two-Junction Cascade Solar Cell with Prismatic Cover Glass," Appl. Phys. Lett., vol. 55, pp. 1741-1743, 1989.

6. J. M. Olson, S. R. Kurtz, A. E. Kibbler, and P. Faine, "A $27.3 \%$ Efficient $\mathrm{Ga}_{0.5}$ In $_{0.5}$ P/GaAs Tandem Solar Cell," Appl. Phys. Lett., 1989.

7. L. Fraas, J. Avery, V. Sundaram, V. Dinh, and T. Davenport, "Tandem Solar Cells with 31\% (AMO) and 37\% (AM1.5D) Energy Conversion Efficiencies," .

8. L. M. Fraas, G. R. Girard, J. E. Avery, B. A. Arau, V. S. Sundaram, A. G. Thompson, and J. Gee, "GaSb Booster Cells for Over 30\% Efficient Solar Cell Stacks," J. Appl. Phys., vol. 66 (8), p. 3866, 15 October 1989.

9. P. D. Demoulin and M. S. Lundstrom, "Projections of GaAs Solar-Cell Performance Limits Based on Two-Dimensional Numerical Simulation," IEEE Trans. Elec. Dev., vol. 36 (5), p. 897, May 1989.

10. C. H. Henry, "Limiting Efficiencies of Ideal Single and Multiple Energy Gap Terrestrial Solar Cells," J. Appl. Phys., vol. 51 (8), p. 4494, August 1980.

11. R. P. Gale, B. D. King, and J. C. C. Fan, "Large-area GaAs CLEFT Layers For Solar Cell Applications," Conf. Rec., 19th IEEE Photovoltaic Specialists Conf., p. 293, IEEE, New York, 1987.

12. O. von Roos, "Influence of Radiative Recombination on the Minority-carrier transport in Direct Bandgap Semiconductors," J. Appl. Phys., vol. 54 (3), p. 1390, March 1983.

13. Toshide Kuriyama, Takeshi Kamiya, and Hisayoshi Yanai, "Effect of Photon Recycling on Diffusion Length and Internal Quantum Efficiency in $\mathrm{Al}_{\mathrm{x}} \mathrm{Ga}_{1-\mathrm{x}} \mathrm{As}-\mathrm{GaAs}$ Heterostructures," Jap. J. Appl. Phys., vol. 16 (3), p. 465, March 1977.

14. P. Asbeck, "Self-absorption Effects on the Radiative Lifetime in GaAs-GaAlAs Double Heterostructures,' J. Appl. Phys., vol. 48 (2), p. 820, February 1977.

15. S. P. Tobin, S. N. Vernon, C. Bajgar, S. J. Wojtczuk, M. R. Melloch, A. Keshavarsi, T. B. Stellwag, S. Venkatesan, M. S. Lundstrom, and K. E. Emery, "Assessment of MOCVDand MBE-Grown GaAs for High-Efficiency Solar Cell Applications," IEEE Trans. Elec. Devices, vol. 37, p. 469, 1990.

16. M. Klausmeier-Brown, "Transistor-based Measurements of Electron Injection Currents in p-type GaAs doped $10^{18}-10^{20} \mathrm{~cm}^{-3}$.," Appl. Phys. Lett., vol. 56 (2), p. 160, 8 January 
1990.

17. H. J. Hovel and J. M. Woodall, "Theoretical and Experimental Evaluations of $\mathrm{Ga}_{1-\mathrm{x}} \mathrm{Al}_{\mathrm{x}} \mathrm{As}-\mathrm{GaAs}$ Solar Cells," Conf. Rec., 10th IEEE Photovoltaic Specialists Conf., p. 25, IEEE, New York, 1973.

18. H. C. Casey, Jr. and M. B. Panish, Heterostructure Lasers, .

19. C. J. Hwang, "Quantum Efficiency and Radiative Lifetime of the Band-to-Band Recombination in Heavily Doped n-type GaAs," Phys. Rev. B, vol. 6 (4), p. 1355, 15 August 1972.

20. R. K. Ahrenkiel, D. J. Dunlavy, B. M. Keyes, S. M. Vernon, S. P. Tobin, and T. M. Dixon, "Design of High Efficiency Solar Cells By Photoluminescence Studies," Conf. Rec., 21st IEEE Photovoltaic Specialists Conf., IEEE, New York, 1990.

21. S. P. Tobin, S. M. Vernon, S. J. Wojtczuk, C. Bajgar, M. M. Sanfacon, and T. M. Dixon, "Advances in High-Efficiency GaAs Solar Cells," Conf. Rec., 21st IEEE Photovoltaic Specialists Conf., IEEE, New York, 1990.

22. J. Zhao, A. Wang, A. W. Blakers, and M. A. Green, "High Efficiency Prismatic Cover Silicon Concentrator Solar Cells," Conf. Rec., 21st IEEE Photovoltaic Specialists Conf., p. 529, IEEE, New York, 1988.

23. Eli Yablanovitch, D. M. Hwang, T. J. Gmitter, L. T. Florez, and J. P. Harbison, "Van der Waals bonding of GaAs epitaxial liftoff films onto arbitraty substrates," Appl. Phys. Lett., vol. 56 (24), p. 2419, 11 June 1990.

24. R. K. Ahrenkiel, D. J. Dunlavy, Brian Keyes, S. M. Vernon, T. M. Dixon, S. P. Tobin, K. L. Miller, and R. E. Hayes, "Ultralong Minority-carrier Lifetime in Epitaxial GaAs by Photon Recycling," Appl. Phys. Letters, vol. 55(11), p. 1088, 11 September 1989.

25. D. Z. Garbuzov, A. N. Ermakova, V. D. Rumyantsev, M. K. Trukan, and V. B. Khalfin, "Multipass Heterostructures. III. Effective Lifetime of Nonequilibrium Carriers," Sov. Phys. Semicond., vol. 11 (4), p. 419, April 1977. 


\section{APPENDIX 1: BIBLIOGRAPHY OF SERI-SUPPORTED PUBLICATIONS}

This appendix lists the various reports, theses, conference presentations, and journal publications that have resulted from research supported under this subcontract. 
Reports:

[1] M. S. Lundstrom, M. R. Melloch, C. S. Kyono, C. P. McMahon, R. E. Noren, and D. P. Rancour, "Basic Studies of III-V High-Efficiency Cell Components," TR-EE-86-35, Aug. 1986, 163 pages.

[2] M. S. Lundstrom, M. R. Melloch, R. F. Pierret, P. D. DeMoulin, D. P. Rancour, C. S. Kyono, M. S. Carpenter, and M.E. Klausmeier-Brown, "Basic Studies of III-V, HighEfficiency Cell Components," TR-EE 87-33, Sept. 1987, 71 pages.

[3] M. S. Lundstrom, M. R. Melloch, R. F. Pierret, M. S. Carpenter, H. L. Chuang, P. D. DeMoulin, M. R. Klausmeier-Brown, G. B. Lush, D. P. Rancour, "Basic Studies of III-V High-Efficiency Cell Components," TR-EE 88-57, Dec. 1988, 109 pages.

[4] M. S. Lundstrom, M. R. Melloch, R. F. Pierret, M. S. Carpenter, H. L. Chuang, A. Keshavarzi, M. E. Klausmeier-Brown, G. B. Lush, and T. B. Stellwag, "Basic Studies of III-V High-Efficiency Cell Components," TR-EE 89-39, September 1989, 111 pages.

Theses:

[5] Christian Paul McMahon, "A Quantum Efficiency Device for Solar Cells," MSEE thesis, August 1986.

[6] Robert E. Noren, "MBE Growth and Characterization of GaAs Heteroface Solar Cells," MSEE thesis, August 1986.

[7] Michael S. Carpenter, "Characterization and Passivation of Gallium Arsenide Surfaces," MSEE thesis, December 1987.

[8] David P. Rancour, "Investigation of GaAs Solar Cell Structures Using Deep Level Transient Spectroscopy," Ph.D. thesis, August 1988.

[9] Martin E. Klausmeier-Brown, "Measurement of the np Product and Minority Carrier Mobility in Heavily Doped p-Type GaAs," Ph.D. Thesis, December 1989.

[10] Theresa B. Stellwag, "A Study of Recombination Mechanisms in Gallium Arsenide $\mathrm{p}^{+} / \mathrm{N}$ Diodes," MSEE Thesis, December 1989.

[11] Hak Lay Harry Chuang, "Experimental Studies and Fabrication Process Development of AlGaAs/GaAs Heterojunction Bipolar Transistors," Ph.D. Thesis, August 1990.

[12] Michael S. Carpenter, "Chemical Passivation of GaAs Surfaces and Devices," Ph.D. Thesis, December 1990.

Conference Presentations:

[13] M. S. Lundstrom and M. R. Melloch, "Basic Studies of III-V High-Efficiency Cell Components," presented at the 7th SERI Photovoltaic Advanced Research and Development Project Review, Denver, CO, May 13-15, 1986.

[14] P. D. DeMoulin, C. S. Kyono, M. S. Lundstrom, and M. R. Melloch, "Dark I-V Characterization of GaAs P/N Heteroface Cells," 19th IEEE Photovoltaic Specialists Conf., New Orleans, LA, May 1987, pp. 93-97.

[15] M. E. Klausmeier-Brown, C-S. Kyono, M. S. Carpenter, M. R. Melloch, M. S. Lundstrom, and R. F. Pierret, "Experimental Characterization of Minority Carrier Mirrors for GaAsBased Solar Cells," Proc. 19th IEEE Photovoltaic Specialist's Conf., New Orleans, May 1987, pp. 1174-1179.

[16] M. S. Lundstrom, "Device Physics of Crystalline Cells," presented at the 8th Photovoltaic Advanced Research and Development Project Review Meeting, Denver, Co, Nov. 16-18, 1987. 
[17] M. E. Klausmeier-Brown, P. D. DeMoulin, M. S. Lundstrom, M. R. Melloch, and S. P. Tobin, "Measurement of Bandgap Narrowing Effects in p-GaAs and Implications for AlGaAs/GaAs HBT Performance," presented at the 46th Device Research Conference, Boulder, CO, June 20-22, 1988.

[18] M. E. Klausmeier-Brown, P. D. DeMoulin, H. L. Chuang, M. S. Lundstrom, M. R. Melloch, and S. P. Tobin, "Influence of Band Gap Narrowing Effects in p ${ }^{+}$GaAs on Solar Cell Performance," Conf. Rec., 20th IEEE Photovoltaic Specialists Conference, Las Vegas, NV, Sept. 26-30, 1988, pp. 503-507.

[19] M. S. Carpenter, M. R. Melloch, B. A. Cowans, and W. N. Delgass, "Investigations of $\left(\mathrm{NH}_{4}\right)_{2} \mathrm{~S}$ Surface Treatments on GaAs," 16th Conference on Physics and Chemistry of Semiconductor Interfaces, Bozeman, Montana, February 7-9, 1989.

[20] M. S. Lundstrom, "Heavy Doping Effects in HBTs," presented at the Workshop on Compound Semiconductor Materials and Devices, WOCSEMMAD, Hilton Head, S.C., Feb. 20-22, 1989.

[21] M. E. Klausmeier-Brown, M. S. Lundstrom, and M. R. Melloch, "Electrical Measurements of Bandgap Shrinkage in Heavily Doped p-type GaAs," presented at the 1989 Electronic Materials Conference, June 21-23, 1989, Boston, MA.

[22] G. B. Lush, T. B. Stellwag, A. Keshavarzi, S. Venkatesan, M. R. Melloch, M. S. Lundstrom and R. F. Pierret, "Correlation of Material Properties and Recombination Losses in $\mathrm{Al}_{0.2} \mathrm{Ga}_{0.8}$ As Solar Cells," presented at the 9th Photovoltaic Advanced Research and Development Review Meeting, Lakewood, CO, May 24-26, 1989.

[23] M. R. Melloch, S. P. Tobin, C. Bajgar, T. B. Stellwag, A. Keshavarzi, M. S. Lundstrom, and K. Emery, "High-Efficiency GaAs Solar Cells Grown by Molecular Beam Epitaxy," Tenth Molecular Beam Epitaxy workshop, Raleigh, NC, September 13-15, 1989.

[24] M. R. Melloch, S. P. Tobin, C. Bajgar, T. B. Stellwag, A. Keshavarzi, M. S. Lundstrom, and K. Emergy, "High-Efficiency GaAs Solar Cells Grown by Molecular Beam Epitaxy," Tenth Molecular Beam Epitaxy Workshop, Raleigh, NC, September 13-15, 1989.

[25] M. S. Lundstrom, M. E. Klausmeier-Brown, and M. R. Melloch, "Electrical Effects of Heavy Doping on GaAs Devices," to be presented at the Vth International Conferences on the Physics of Semiconductor Devices, New Delhi, India, Dec. 1989 (INVITED).

[26] T. B. Stellwag, P. E. Dodd, M. S. Carpenter, M. S. Lundstrom, R. F. Pierret, and M. R. Melloch, "Effects of Perimeter Recombination on GaAs-Base Solar Cells," presented at the 21st IEEE Photovoltaic Spec. Conf., 1990.

[27] M. E. Klausmeier-Brown, M. R. Melloch, and M. S. Lundstrom, "Effects of Heavy Impurity Doping on the np Product in GaAs," presented at the 21st IEEE Photovoltaic Spec. Conf., 1990.

[28] M. R. Melloch, S. P. Tobin, C. Bajgar, T. B. Stellwag, A. Keshavarzi, and M. S. Lundstrom, "High-Efficiency GaAs and AlGaAs Solar Cells Grown by Molecular Beam Epitaxy," presented at the 21st IEEE Photovoltaic Spec. Conf., 1990.

\section{Journal Publications:}

[29] M. R. Melloch, C. P. McMahon, M. S. Lundstrom, J. A. Cooper, Jr., Q-D. Qian, and S. Bandyopadhyay, "Bias-Dependent Photoresponse of $\mathrm{p}^{+}$in GaAs/AlAs/GaAs Diodes," Appl. Phys. Lett., Vol. 50, p. 161-163, Jan. 19, 1987.

[30] M. R. Melloch, C. P. McMahon, M. S. Lundstrom, J. A. Cooper, Jr., and Q-D. Qian, "Photocollection Efficiency of GaAs/AlAs/GaAs $\mathrm{p}^{+}$in and $\mathrm{n}^{+}$ip Photodiodes," Solar Cells, pp. 233-240, June-August 1987.

[31] D. Rancour, M. R. Melloch, R. F. Pierret, M. S. Lundstrom, M. E. Klausmeier-Brown and C. S. Kyono, "Recombination Current Suppression in GaAs P-N Junctions Grown on AlGaAs Buffer Layers by Molecular Beam Epitaxy," J. Appl. Phys., Vol. 62, pp. 1539- 
1541, Aug. 15, 1987.

[32] M. S. Lundstrom, "Device Physics of Crystalline Solar Cells," Solar Cells, Vol. 24, pp. 91102, May-June 1988.

[33] M. S. Carpenter, M. R. Melloch, M. S. Lundstrom, and S. P. Tobin, "Effects of $\mathrm{Na}_{2} \mathrm{~S}$ and $\left(\mathrm{NH}_{4}\right)_{2} \mathrm{~S}$ Edge Passivation Treatments on the Dark Current-Voltage Characteristic of GaAs pn Diodes," Applied Physics Letters, Vol. 52, pp. 2157-2159, June 20, 1988.

[34] M. E. Klausmeier-Brown, M. S. Lundstrom, M. R. Melloch, and S. P. Tobin, "Effects of Heavy Impurity Doping on Electron Injection in $\mathrm{p}^{+}-\mathrm{n}$ GaAs Diodes," Applied Physics Letters, Vol. 52, pp. 2255-2257, June 27, 1988.

[35] M. E. Klausmeier-Brown, C. S. Kyono, P. D. DeMoulin, S. P. Tobin, M. S. Lundstrom, and M. R. Melloch, "Sequential Etch Analysis of Electron Injection in $\mathrm{P}^{+} \mathrm{GaAs}$," IEEE Trans. Electron Devices, Vol. ED-35, pp. 1159-1161, July 1988.

[36] M. S. Carpenter, M. R. Melloch, and T. E. Dungan, "Schottky Barrier Formation on $\left(\mathrm{NH}_{4}\right)_{2}$ S-treated n- and p-type (100) GaAs," Appl. Phys. Lett. 53, pp. 66-68, July 4, 1988.

[37] P. D. DeMoulin, S. P. Tobin, M. S. Lundstrom, M. S. Carpenter, and M. R. Melloch, "Influence of Perimeter Recombination on High-Efficiency GaAs P/N Heteroface Solar Cells," Electron Device Letters, Vol. EDL-9, pp. 368-370, August 1988.

[38] H. L. Chuang, P. D. DeMoulin, M. E. Klausmeier-Brown, M. R. Melloch, and M. S. Lundstrom, "Evidence for Bandgap Narrowing Effects in Be-Doped, p-p ${ }^{+}$GaAs Homojunction Barriers," Journal of Appl. Phys., Vol. 64, pp. 6361-6364, Nov. 1988.

[39] B. A. Cowans, Z. Dardas, W. N. Delgass, M. S. Carpenter, and M. R. Melloch, "X-ray Photoelectron Spectroscopy of Ammonium Sulfide Treated GaAs (100) Surfaces," Appl. Phys. Letz., Vol. 54, pp. 365-367, January 23, 1989.

[40] D. P. Rancour, R. F. Pierret, M. S. Lundstrom and M. R. Melloch, "Application of Isothermal Current Deep Level Transient Spectroscopy to Solar Cells," J. Appl. Phys., Vol. 65, pp. 2173-2176, March 1, 1989.

[41] H. L. Chuang, M. E. Klausmeier-Brown, M. R. Melloch, and M. S. Lundstrom, "Effective Minority Carrier Hole Confinement of Si-doped, $\mathrm{n}^{+} / \mathrm{n}$ GaAs Homojunction Barriers," $J$. Appl. Phys., Vol. 66, pp. 273-278, July 1989.

[42] M. S. Carpenter, M. R. Melloch, B. A. Cowans, Z. Dardas, and W. N. Delgass, "Investigations of Ammonium Sulfide Surface Treatments on GaAs," Journal of Vacuum Science and Technology B, Vol. 7, July-August 1989.

[43] M. S. Lundstrom, M. E. Klausmeier-Brown, and M. R. Melloch, "Effects of Heavy Impurity Doping on AlGaAs/GaAs Bipolar Transistors," IEEE Trans. Electron Dev., Vol. 36, Oct. 1989.

[44] M. R. Melloch, S. P. Tobin, T. B. Stellwag, C. Bajgar, A. Keshavarzi, M. S. Lundstrom, and K. Emery, "High-Efficiency GaAs Solar Cells Grown by Molecular Beam Epitaxy," Journal of Vacuum Science and Technology B, Vol. 8, March-April 1990.

[45] S. P. Tobin, S. M. Vernon, C. Bajgar, S. J. Wojtczuk, M. R. Melloch, A. Keshavarzi, T. B. Stellwag, S. Venkatesan, M. S. Lundstrom, and K. A. Emery, "Assessment of MOCVDand MBE-Grown GaAs for High-Efficiency Solar Cell Applications, IEEE Trans. Electron Devices, Vol. 37, pp. 469-477, 1990.

[45] G. B. Lush, T. B. Stellwag, A. Keshavarzi, S. Venkatesan, M. R. Melloch, M. S. Lundstrom and R. F. Pierret, "Correlation of Material Properties and Recombination Losses in $\mathrm{Al}_{0.2} \mathrm{Ga}_{0.8}$ As Solar Cells," Solar Cells, Vol. 27, pp. 363-372, 1990.

[46] M. E. Klausmeier-Brown, M. R. Melloch, and M. S. Lundstrom, "Electrical Measurements of Bandgap Shrinkage in Heavily Doped p-type GaAs," Journal of Electronic Materials, Vol. 19, pp. 7-11, 1990 
[47] M. E. Klausmeier-Brown, M. R. Melloch, and M. S. Lundstrom, "Transistor-Based Measurements of Electron Injection Currents in p-type GaAs doped $10^{18}$ to $10^{20} \mathrm{~cm}^{-3}, " \mathrm{Appl}$. Phys. Lett., Vol. 56, pp. 160-162, 1990.

[48] T. B. Stellwag, M. R. Melloch, M. S. Lundstrom, M. S. Carpenter, and R. F. Pierret, "Orientation-Dependent Perimeter Recombination in GaAs Diodes," Appl. Phys. Lett., Vol. 56, pp. 1658-1660, 1990.

[49] M. S. Lundstrom, M. E. Klausmeier-Brown, M. R. Melloch, R. K. Ahrenkiel, and B. M. Keyes, "Device-Related Material Properties of Heavily Doped Gallium Arsenide," SolidState Electronics, Vol. 6, pp. 693-704, 1990.

[50] M. R. Melloch, S. P. Tobin, Bajgar, A. Keshavarzi, T. B. Stellwag, G. B. Lush, M. S. Lundstrom and $\mathrm{K}$. Emery, "High Efficiency $\mathrm{Al}_{0.22} \mathrm{Ga}_{0.78}$ As Solar Cells Grown by Molecular Beam Epitaxy," Appl. Phys. Lett., Vol. 57, pp. 52-54, 1990.

[51] H. L. Chuang, M. S. Carpenter, M. R. Melloch, M. S. Lundstrom, E. Yablonovitch, and T. J. Gmitter, "Surface Passivation Effects of $\mathrm{As}_{2} \mathrm{~S}_{3}$ Glass on Self-Aligned AlGaAs/GaAs Heterojunction Bipolar Transistors," submitted to Appl. Phys. Lett.

[52] P. E. Dodd, T. B. Stellwag, M. R. Melloch, and M. S. Lundstrom, "Surface and Perimeter Recombination in GaAs Diodes: An Experimental and Theoretical Investigation," submitted to IEEE Trans. Electron Dev.

[53] M. R. Melloch, E. S. Harmon, and K. A. Emery, "Large Area, $8 \mathrm{~cm}^{2} \mathrm{GaAs}$ Solar Cells Fabricated from MBE Material," submitted to IEEE Elec. Dev. Lett. 


\begin{tabular}{|c|c|c|c|}
\hline $\begin{array}{l}\text { Document Control } \\
\text { Page }\end{array}$ & $\begin{array}{l}\text { 1. NREL Report No. } \\
\text { NREL/TP-451-4850 }\end{array}$ & $\begin{array}{l}\text { 2. NTIS Accession No. } \\
\text { DE92010563 }\end{array}$ & 3. Recipient's Accession No. \\
\hline \multirow{3}{*}{\multicolumn{3}{|c|}{$\begin{array}{l}\text { 4. Title and Subtitle } \\
\text { Basic Studies of III-V High Efficiency Cell Components }\end{array}$}} & 5. Publication Date \\
\hline & & & January 1993 \\
\hline & & & 6. \\
\hline \multicolumn{3}{|c|}{$\begin{array}{l}\text { 7. Author(s) } \\
\text { M.S. Lundstrom, M.R. Melloch, R.F. Pierret, M.S. Carpenter, H.L. Chuang, } \\
\text { P.E. Dodd, A. Keshavarzi, M.E. Klausmeier-Brown, G.B. Lush, T.B. Stellwag }\end{array}$} & 8. Performing Organization Rept. No. \\
\hline \multirow{2}{*}{\multicolumn{2}{|c|}{$\begin{array}{l}\text { Purdue University } \\
\text { School of Electrical Engineering } \\
\text { West Lafayette, Indiana } 47907\end{array}$}} & & $\begin{array}{l}\text { 10. Project/Task/Work Unit No. } \\
\text { PV221103 }\end{array}$ \\
\hline & & & $\begin{array}{l}\text { 11. Contract (C) or Grant (G) No. } \\
\text { (C) XL-5-0518-1 } \\
\text { (G) }\end{array}$ \\
\hline \multirow{2}{*}{\multicolumn{3}{|c|}{$\begin{array}{l}\text { 12. Sponsoring Organization Name and Address } \\
\text { National Renewable Energy Laboratory } \\
1617 \text { Cole Blvd. } \\
\text { Golden, CO } 80401-3393\end{array}$}} & $\begin{array}{l}\text { 13. Type of Report \& Period Covered } \\
\text { Technical Report } \\
15 \text { August } 1989-14 \text { August } 1990\end{array}$ \\
\hline & & & 14. \\
\hline \multicolumn{4}{|c|}{$\begin{array}{l}\text { 15. Supplementary Notes } \\
\text { NREL technical monitor: J. Benner }\end{array}$} \\
\hline \multicolumn{4}{|c|}{ 16. Abstract (Limit: 200 words) } \\
\hline \multicolumn{4}{|c|}{$\begin{array}{l}\text { This report describes research activities on this subcontract for the last year. Other research is described in the reprints } \\
\text { contained in Appendix } 1 \text {. Chapter } 1 \text { describes experimental and theoretical work on perimeter and surface recombination. It } \\
\text { describes measurements -to characterize such recombination as well as the extension of the PUPHS2D model to treat these } \\
\text { effects. Chapter } 2 \text { describes a new surface passivation treatment, } A_{2} \mathrm{~S}_{3} \text {, which appears to produce a permanent reduction of } \\
\text { surface recombination. Chapter } 3 \text { describes collaboration with outside laboratories to fabricate and characterize a variety of } \\
\text { high-efficiency cells using films grown by molecular beam epitaxy. Chapter } 4 \text { presents some thoughts on how innovative } \\
\text { designs might be used to advantage for III-V cells. Appendix } 1 \text { is a complete list of the publications that have resulted during } \\
\text { the course of the project. }\end{array}$} \\
\hline \multirow{2}{*}{\multicolumn{4}{|c|}{$\begin{array}{l}\text { 17. Document Analysis } \\
\text { a. Descriptors } \\
\text { III-V cells; high efficiency ; photovoltaics ; solar cells }\end{array}$}} \\
\hline & & & \\
\hline \multicolumn{4}{|l|}{$\begin{array}{l}\text { c. UC Categories } \\
273\end{array}$} \\
\hline \multirow{2}{*}{\multicolumn{2}{|c|}{$\begin{array}{l}\text { 18. Availability Statement } \\
\text { National Technical Information Service } \\
\text { U.S. Department of Commerce } \\
\text { 5285 Port Royal Road } \\
\text { Springfield, VA } 22161\end{array}$}} & & $\begin{array}{l}\text { 19. No. of Pages } \\
68 \\
\end{array}$ \\
\hline & & & $\begin{array}{r}\text { 20. Price } \\
\text { A04 }\end{array}$ \\
\hline
\end{tabular}

